Medlock, S., Eslami, S., Askari, M., Taherzadeh, Z., Opondo, D., Rooij, S.E. de, Abu-Hanna, A. Co-prescription of gastroprotective agents and their efficacy in elderly patients taking nonsteroidal anti-inflammatory drugs: a systematic review of observational studies. Clinis Gastroenterology and Hepatology: 2013, 11(10), 1259-1269

\begin{tabular}{l|l}
$\begin{array}{l}\text { Postprint } \\
\text { Version }\end{array}$ & 1.0 \\
\hline Journal website & http://www.sciencedirect.com/science/article/pii/S1542356513008033\# \\
\hline Pubmed link & $\underline{\text { http://www.ncbi.nlm.nih.gov/pubmed/?term=23792548 }}$ \\
\hline DOI & $10.1016 /$ j.cgh.2013.05.034
\end{tabular}

This is a NIVEL certified Post Print, more info at http://www.nivel.eu

\title{
Co-prescription of Gastroprotective Agents and Their Efficacy in Elderly Patients Taking Nonsteroidal Anti-inflammatory Drugs: A Systematic Review of Observational Studies
}

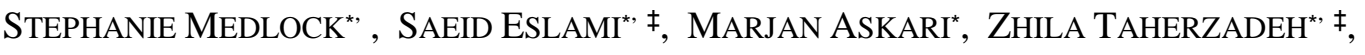 \\ DEDAN OPONDO*, §, SOPHIA E. DE RoOIJ", AMEEN ABU-HANNA* \\ * Department of Medical Informatics, Academic Medical Center, University of Amsterdam, \\ Amsterdam, the Netherlands \\ " Section of Geriatric Medicine, Department of Internal Medicine, Academic Medical Center, \\ University of Amsterdam, Amsterdam, the Netherlands \\ ‡ Pharmaceutical Research Center, School of Pharmacy, Mashhad University of Medical \\ Sciences, Mashhad, Iran \\ § NIVEL (Netherlands Institute for Health Care Research), Utrecht, the Netherlands
}

Background \& Aims: Guidelines recommend prescribing gastroprotective agents (proton pump inhibitors, misoprostol) to older patients (primarily $\geq 65$ years old) taking nonsteroidal anti-inflammatory drugs (NSAIDs) to prevent gastrointestinal ulcers. Older individuals are underrepresented in clinical trials of these agents. We systematically reviewed evidence from observational studies on the use of gastroprotective agents in elderly patients and their ability to prevent NSAID-related ulcers in this population.

Methods: We performed a systematic search of Embase and MEDLINE and identified 23 observational studies that focused on elderly patients and reported data on co-prescription of gastroprotective agents and NSAIDs and/or the effectiveness of the agents in preventing gastrointestinal events in NSAID users. We collected data on rates of co-prescription and NSAID-related gastrointestinal events in patients with and without gastroprotection.

Results: A median of $24 \%$ (range, $10 \%-69 \%$ ) of elderly patients taking NSAIDs received a co-prescription for gastroprotective agents; this percentage was only slightly higher in the oldest age groups. All studies of efficacy showed a positive effect of gastroprotection. However, the adjusted results were not suitable for synthesis, and the 5 studies reporting unadjusted results were too heterogeneous for meta-analysis (I2 = 97\%). The studies differed in outcomes, definitions of 
Medlock, S., Eslami, S., Askari, M., Taherzadeh, Z., Opondo, D., Rooij, S.E. de, Abu-Hanna, A. Co-prescription of gastroprotective agents and their efficacy in elderly patients taking nonsteroidal anti-inflammatory drugs: a systematic review of observational studies. Clin Gastroenterology and Hepatology: 2013, 11(10), 1259-1269

co-prescription, and differences in baseline risk factors between patients with and without gastroprotection. None of the studies assessed adverse effects of gastroprotective agents. The 2 cost-effectiveness studies reached opposing conclusions.

Conclusions: In a systematic review, the observational evidence for the efficacy of gastroprotective agents in preventing NSAID-associated gastrointestinal events was in agreement with results of randomized controlled trials. However, because of heterogeneity of included studies, it is not clear what the effect would be if more patients were treated, or at what age gastroprotection should be recommended. We offer suggestions to facilitate comparison with other work and address the questions of risk and benefit in relation to age.

\section{Abbreviations used in this paper}

CI, confidence interval;

COX-2, cyclooxygenase-2;

GI, gastrointestinal;

H2RA, histamine-2 receptor antagonist;

NS, nonselective;

NSAID, nonsteroidal anti-inflammatory drug;

OR, odds ratio;

PPI, proton pump inhibitor;

$\mathrm{RR}$, relative risk

As the population ages, care of older patients is becoming increasingly important. With age comes an increased incidence of chronic disease and disabilities, often accompanied by pain. Pain control is fundamental to maintaining quality of life, and nonsteroidal anti-inflammatory drugs (NSAIDs) are commonly prescribed for control of pain and inflammation in elderly patients. ${ }^{1}$ However, use of NSAIDs carries a risk of adverse events, ${ }^{2}$ including gastrointestinal (GI) ulceration and bleeding, which can lead to hospitalization and mortality. ${ }^{3}$ Metabolism of medications and pharmacokinetics change with age, ${ }^{1}$ and older patients are also more likely to have conditions or medications that put them at increased risk for GI symptoms associated with NSAID use. ${ }^{1 \text { and } 4}$

Guidelines recommend gastroprotection for high-risk patients taking nonselective (NS)-NSAIDs, particularly proton pump inhibitors (PPIs) or misoprostol for older patients (defined as older than 65 or 70 years of age in most

guidelines; Supplementary Table 1). 6, 7, 8, 9 and 10 A Cochrane review of the evidence for the efficacy of gastroprotection to prevent endoscopic ulcers in high-risk patients showed that $800 \mu \mathrm{g} /$ day misoprostol had an adjusted relative risk (RR) of 0.17 , double-dose histamine-2 receptor antagonists (H2RAs) had an RR of 0.44, and PPIs had an RR of $0.40 .^{11}$

\section{Applicability of Evidence From Clinical Trials to Elderly Patients}

There is reason to believe that the clinical trials may not be directly applicable to

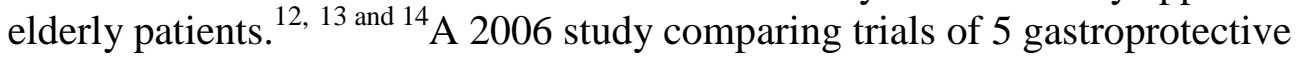


Medlock, S., Eslami, S., Askari, M., Taherzadeh, Z., Opondo, D., Rooij, S.E. de, Abu-Hanna, A. Co-prescription of gastroprotective agents and their efficacy in elderly patients taking nonsteroidal anti-inflammatory drugs: a systematic review of observational studies. Clinicat Gastroenterology and Hepatology: 2013, 11(10), 1259-1269

strategies suggested that elderly patients may benefit more from misoprostol or H2RAs but not cyclooxygenase-2 (COX-2) selective NSAIDs. ${ }^{15}$ Older patients may also be more prone to adverse effects from the gastroprotective agents themselves, including more serious problems such as fractures, ${ }^{16}$ pneumonia, ${ }^{17}$ Clostridium difficile infection, ${ }^{18}$ and others. ${ }^{19}$ and ${ }^{20}$ Finally, elderly patients are often excluded from clinical trials, ${ }^{21}$ and 22 and there is evidence that elderly people are underrepresented in the trials in the Cochrane review. Because the average age of NSAID users is older than 65 years ${ }^{23}$ clinical trials of NSAID users should also have an average age of older than 65 years. Only 1 trial specifically studied older patients (>60 years of age), reporting 8 ulcers in 53 patients receiving ibuprofen and no ulcers in 60 patients receiving ibuprofen/misoprostol. ${ }^{24}$ Only 5 of the other 38 studies in the Cochrane review had an average participant age of older than 65 years (Supplementary Table 2), ${ }^{25,26,27,28 \text { and } 29}$ and none performed a subgroup analysis for patients older than 65 years. Although it is known that risk of a GI event increases with age and decreases with gastroprotection, evidence is lacking as to at what age co-prescription is indicated and for what patients the risks of therapy may outweigh the benefits.

Recent meta-analyses have shown that high-quality observational studies provide similar results to high-quality randomized controlled trials. ${ }^{30,31}$ and 32 Populationbased observational studies can better represent elderly patients as encountered in daily practice, including those with multiple morbidities and complex medications. Gastroprotective agents are commonly used by elderly patients for gastroesophageal reflux disease and other indications. Patients with those indications are often at higher risk of GI events; thus the rate of co-prescription is important for determining what the effect might be if the entire population were treated.

Therefore, the objectives of this review were to assess the effectiveness of gastroprotective agents in clinical practice for prevention of GI ulceration related to NSAID use in elderly patients, quantitatively synthesize the evidence where possible, and assess the rate of co-prescription of gastroprotective agents with NSAIDs in elderly patients.

\section{METHODS}

\section{Data Sources and Search}

A researcher (S.E.) systematically searched Embase and MEDLINE for articles with the terms elderly,seniors, or 65 years; nonsteroidal anti-inflammatory drugs or NSAIDs; and gastroprotective agents,histamine 2 blockers, or proton pump inhibitors in the title, abstract, subject headings, or keywords (details of search in the Supplementary Appendix). The search was last performed on March 14, 2013.

\section{Study Selection}

Two authors (S.E. and Z.T.) independently selected articles for full-text screening on the basis of title and abstract, with disagreements resolved by discussion. Inter-rater agreement was assessed by using Cohen's K (R 2.11.1; The R Foundation for Statistical Computing, package irr $^{33}$ ). Two authors (S.M. and S.E.) evaluated the full text for inclusion in the study and extracted the data. References of the included articles were checked for additional studies. 
Medlock, S., Eslami, S., Askari, M., Taherzadeh, Z., Opondo, D., Rooij, S.E. de, Abu-Hanna, A. Co-prescription of gastroprotective agents and their efficacy in elderly patients taking nonsteroidal anti-inflammatory drugs: a systematic review of observational studies. Clin Gastroenterology and Hepatology: 2013, 11(10), 1259-1269

The inclusion criteria were the following:

(1) The study is an observational study of clinical practice.

(2) The study population is elderly; the study explicitly includes only patients $\geq 65$

years, has an average patient age $\geq 65$, or presents any subgroup stratified by an age $\geq 65$ years.

(3) The study must report the rate of concomitant prescription of NSAIDs and gastroprotective agents (co-prescription studies) and/or the effectiveness of gastroprotective agents at prevention of NSAID-related GI events (efficacy studies). (4) The study is published in the English language.

Studies were included for full-text screening if the abstract indicated that the main subject of the study was the rate of co-prescription or efficacy of gastroprotective agents in NSAID users, and older age was mentioned as a factor that was assessed in the study. All studies published before January 1, 2013 were eligible for inclusion.

\section{Data Extraction and Quality Assessment}

Included studies were classified as co-prescription, efficacy, or both. We recorded the size, setting, objective, study design, and inclusion criteria. Drug exposure was assessed in terms of NSAID and gastroprotective agent exposure (which medications were assessed, dose, duration, incident or prevalent use, and consideration of overthe-counter exposure) and the criteria defining a co-prescription. We recorded the outcomes assessed, including adverse effects from the gastroprotective agents. From the co-prescription studies, we recorded the rate of co-prescription for patients over 65 , the rate of co-prescription for any subgroups with age over 65, and factors influencing co-prescription. For meta-analysis of efficacy studies, we recorded the follow-up time, clinical outcome, the unadjusted number of patients with and without the clinical outcome, the adjusted result, and variables used in adjustment. Risk of bias was assessed by using the criteria proposed in the risk of bias section of the Grading of Recommendations Assessment, Development, and Evaluation system by Guyatt et $\mathrm{al}^{34}$ (assessing eligibility criteria, measurement of exposure and outcome, control for confounding, and completeness of follow-up).

\section{Data Synthesis and Analysis}

We assessed heterogeneity $\left(\mathrm{I}^{2}\right)$ and the cumulative odds ratio (OR) by using a random effects model and assessed the risk of publication bias by using a funnel plot (RevMan 5.1.4; The Cochrane Collaboration). If the results of the meta-analysis were not reliable, then the cumulative OR would not be reported. We also recorded predictors of NSAID-associated GI events as reported in each study.

\section{RESULTS}

The search results are illustrated in Figure 1. The search yielded 223 articles, of which 30 were provisionally included on the basis of title and abstract. Inter-rater agreement was high $(\mathrm{K}=0.98)$. Review of the full text retained 23 articles. Characteristics of the included studies are summarized in Table 1, with further details inSupplementary Table 3. Five studies reported both the rate of co-prescription and the efficacy of PPIs for prevention of GI events, ${ }^{35,36,37,38 \text { and } 39}$ fourteen reported 
Medlock, S., Eslami, S., Askari, M., Taherzadeh, Z., Opondo, D., Rooij, S.E. de, Abu-Hanna, A. Co-prescription of gastroprotective agents and their efficacy in elderly patients taking nonsteroidal anti-inflammatory drugs: a systematic review of observational studies. Clinicat Gastroenterology and Hepatology: 2013, 11(10), 1259-1269

only on co-prescription, 40, 41, 42, 43, 44, 45, 46, 47,48, 49, 50, 51, 52 and 53 and 3 reported only on efficacy. ${ }^{54,55}$ and 56 A study reporting on the therapeutic intent of PPIs coprescribed with NSAIDs was also included. ${ }^{57}$

\section{[TABLE 1] [FIGURE 2]}

\section{Co-prescription}

Table 1 shows the rate of co-prescription of NS-NSAIDs with gastroprotective agents. The rate of co-prescription for patients aged 65 and older was reported in 19 studies, ${ }^{35}, 36,37,38,39,40,41,42,43,44,45,46,47,48,49,50,51,52$ and 53 with rates ranging from $10.2 \%{ }^{41}$ to $69.4 \%^{53}$ (median, $23.6 \%$ ). The rate of co-prescription in these patients is shown in relation to the study period in Figure 2.

\section{[TABLE 2]}

\section{Effect of age on prescribing behavior}

Eleven studies investigated the effect of age on the rate of coprescription. ${ }^{37,39,40,41,42,44,47,48,49,50 \text { and } 53}$ Increasing age was positively associated with increasing rates of co-prescription in 8 of 11 studies. $37,39,40,41,42,48,49$ and 50 Four studies compared older patients with younger patients with 1 or more risk factors and found an adjusted OR of 4.1, confidence interval (CI), 2.3-7.4 (reference category, 18-45 years) ${ }^{40}$; an adjusted OR of 1.71, CI, 1.30-2.23 (reference category, 50-65 years) ${ }^{48}$; no difference in rate of co-prescription for young low-risk patients (57.5\%), young high-risk patients (69.4\%), and older patients $(69.4 \%)^{53}$; and that other factors predicted co-prescription better than age (adjusted OR, 3; CI, 2.3-4.1). ${ }^{50}$ The other 7 studies included only patients aged 65 and older. One reported an adjusted OR of 1.11 (CI, 1.03-1.91) for patients $\geq 75$ years compared with those $<75$ years, ${ }^{42}$ and another reported a hazard ratio of 1.02 (CI, 1.02-1.02) per year. ${ }^{37}$ Five reported differences per age category: significant differences per 10 -year category, ${ }^{39}$ adjusted OR (significant for age $\geq 85$, OR, 1.12; CI, 1.02-1.22) ${ }^{41}$ a nonsignificant increase per 5 years, ${ }^{44}$ a nonsignificant decrease per 5 years, ${ }^{47}$ and significantly higher rates of prevalent but not incident use of gastroprotective agents starting at 80 years of age (per 5-year category) (OR, 1.28; CI, 1.12-1.43 and OR, 1.10; CI, 0.83-1.46, respectively). ${ }^{49}$ Two studies reported the rates of co-prescription per 5-year age category but did not analyze them. ${ }^{38}$ and 51 In all studies reporting the rate of co-prescription with respect to age, the largest absolute difference was $9.6 \%(22.3 \%$ in ages $65-70$ and $31.9 \%$ in ages $>85) .{ }^{51}$

\section{Other factors influencing prescribing behavior}

Eleven of the included studies reported on statistically significant predictors of coprescription. Apart from age, only a few factors were investigated in more than 2 studies. These factors included a history of upper GI problems (significant in 7 of 7

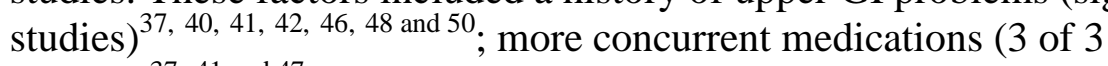
studies), ${ }^{37,41}$ and 47 particularly corticosteroids (7 of 7

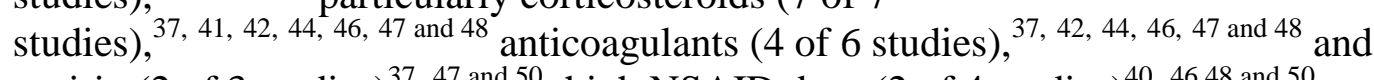

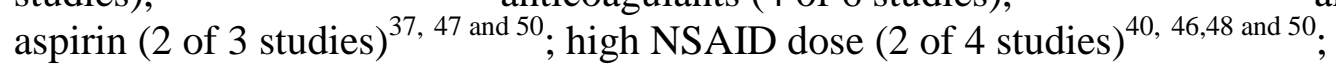


Medlock, S., Eslami, S., Askari, M., Taherzadeh, Z., Opondo, D., Rooij, S.E. de, Abu-Hanna, A. Co-prescription of gastroprotective agents and their efficacy in elderly patients taking nonsteroidal anti-inflammatory drugs: a systematic review of observational studies. Clinic Gastroenterology and Hepatology: 2013, 11(10), 1259-1269

duration of prescription (positively associated in one study, ${ }^{49}$ negatively associated in one study, ${ }^{46}$ and nonsignificant in the third ${ }^{50}$ ); and female gender ( 4 of 7 studies). ${ }^{37}, 40,42,44,47,48$ and 50 Three studies investigated the influence of the type of NSAID. Indomethacin and ketoprofen were significantly associated with higher rates of co-prescription in all 3 studies, ${ }^{44,} 47$ and 48 but other NSAIDs were also significant in each study. An additional 41 factors were investigated in 1 or 2 studies, including economic status, race, previous NSAID tolerance, and year of prescription.

\section{Study quality and risk of bias}

Most of the studies in this category had a low risk of bias in inclusion criteria, because they included all patients in a region or hospital or all patients with exposure to study medications, although 3 studies asked doctors to voluntarily include patients. ${ }^{40,50 \text { and } 53}$ Risk of bias in measurement of exposure and outcome was also low in most studies, although the same 3 studies relied on exposure and outcome reporting by participating doctors and also reported the highest rates of coprescription. The definition of exposure and outcome (co-prescription) varied widely. Definition of NSAID exposure varied in the types of NSAIDs (COX-2s, NSNSAIDs, aspirin, and/or acetaminophen), dose, duration, and whether incident (new) users or prevalent users were included (Supplementary Table 3). The definition of exposure to gastroprotective agents also varied by class (PPIs, misoprostol, H2RAs, and/or sucralfate), dose, duration, and incident or prevalent use. The definition of coprescription varied from prescription by the same doctor on the same day, ${ }^{44}$ to any overlap in use, ${ }^{38,} 39$ and 54 to prescription within the same year. ${ }^{51}$ A sensitivity analysis of this definition was performed or referenced in 7 studies (Supplementary Table 3). ${ }^{37,38,39,44,48,49 \text { and } 54}$

\section{Efficacy}

Eight studies reported on efficacy. ${ }^{35,36,37,38,39,54,55 \text { and } 56}$ Five reported the incidence of GI events in patients taking NS-NSAIDs ${ }^{36,37,38 \text { and } 39}$ or low-dose aspirin ${ }^{35}$ with or without a concomitant PPI (Table 2). All 5 investigated PPI use in patients older than 65 years of age, with 2 in the same population. ${ }^{37}$ and 38 Three of the 5 were population-based, representing 1 national cohort ${ }^{39}$ and 1 regional cohort. ${ }^{37}$ and 38 The other 2 consisted of a referral center population ${ }^{35}$ and a national sample from participating general practices. ${ }^{36}$ The forest plot in Figure 3 shows little overlap in the CIs, indicating high heterogeneity $\left(\mathrm{I}^{2}=97 \%\right)$. The study investigating low-dose aspirin $^{35}$ was included in the analysis because aspirin has also been shown to be associated with GI bleeding (mitigated by use of PPIs), ${ }^{58}$ and excluding this study did not reduce the heterogeneity $\left(\mathrm{I}^{2}=98 \%\right)$. Meta-analysis will not provide reliable results with high heterogeneity, ${ }^{59}$ and assessment and adjustment for heterogeneity cannot be performed with a small number of studies. ${ }^{60}$ Likewise, the funnel plot (Supplementary Figure 1) is not considered reliable with fewer than 10 studies. ${ }^{61}$ Potential sources of heterogeneity include differences in the choice of outcome measure (self-reported GI complaints, ${ }^{36}$ GI hospitalization rate, ${ }^{37 \text { and } 38}$ hospitalization with upper GI event, ${ }^{39}$ and 54 ulcers found on endoscopy, ${ }^{35}$ or serious ulcer complications ${ }^{55}$ and 56 ), the definitions of drug exposure and co-prescription, and differences in prescribing behavior leading to greater or lesser differences in baseline risk between treated and untreated patients. Three of these $5^{37,38 \text { and } 39}$ plus an additional 2 studies ${ }^{54 \text { and } 55}$ reported efficacy of PPIs after 
Medlock, S., Eslami, S., Askari, M., Taherzadeh, Z., Opondo, D., Rooij, S.E. de, Abu-Hanna, A. Co-prescription of gastroprotective agents and their efficacy in elderly patients taking nonsteroidal anti-inflammatory drugs: a systematic review of observational studies. Clin Gastroenterology and Hepatology: 2013, 11(10), 1259-1269

adjustment for various risk factors (Table 2) but did not report outcome measures that could be combined. In addition, these 5 studies took place in only 3 distinct populations.

\section{[TABLE 2] [FIGURE 3]}

All studies reported a significant benefit for patients co-prescribed PPIs while taking NSAIDs. One of the 2 cost-effectiveness studies reported that co-prescription was not cost-effective (net cost of $€ 4907$, approximately $\$ 6900$ US, per ulcer complication prevented, which is based on the average cost of treating a complicated ulcer), ${ }^{56}$ and the other concluded that it was cost-effective (50\% overall cost reduction, which is based on individual medical, radiologic, and surgical costs). ${ }^{54}$

\section{Risk factors for gastrointestinal events in elderly nonsteroidal anti-inflammatory drug users}

Four studies reported on statistically significant independent predictors of GI ulceration or hospitalization for a GI problem. ${ }^{37,38,39 \text { and } 55}$ Use of PPIs was significantly protective, ${ }^{37,38,39 \text { and } 55}$ and age was a significant risk factor in all studies that assessed it. ${ }^{37,} 38$ and 39 No other risk factor was consistently significant, although female gender tended to be protective, ${ }^{37,} 38$ and 39 and use of anticoagulants, corticosteroids, or aspirin tended to increase risk. ${ }^{37,38,39 \text { and } 55}$ An additional 23 factors were investigated by 1 or 2 studies, including use of other medications and use of coxibs.

\section{Study quality and risk of bias}

These 8 studies carry a low risk of bias in their eligibility criteria (Table 2). Five were population-based $^{37,38,39 \text { and } 54}$ or included all patients in the hospital database, ${ }^{57}$ and 2 included successive patients undergoing endoscopy ${ }^{35}$ or visiting participating general practices. ${ }^{36}$ One was a case-control study including all admissions to the regional hospital with NSAID-related ulcers, ${ }^{56}$ which acknowledged the limitation that no age-matched controls could be found for the oldest patients diagnosed with NSAID-related ulcers. ${ }^{55}$ Four studies used sensitivity analysis or comparison of different measures of exposure. ${ }^{37,38,39 \text { and } 54}$ The outcome measures pose little risk of bias, with the exception of 1 study that used patient surveys. ${ }^{36}$ Five studies reported an outcome adjusted for various confounders, ${ }^{37,38,39,54 \text { and } 55}$ and 2 reported unadjusted results. ${ }^{35}$ and 36 Follow-up time was adequate in all studies.

\section{Use of Nonsteroidal Anti-inflammatory Drugs and Proton Pump Inhibitors/Gastroprotective Agents in the Elderly Population}

Seven studies reported on the use of NSAIDs among elderly patients or on the use of gastroprotective agents in patients who do not use NSAIDs (Table 3). ${ }^{44,45,47,48,49,51 \text { and } 52}$ The single study investigating the indication given for coprescribing gastroprotective agents with NSAIDs found that 949 of 1069 prescriptions described an "appropriate therapeutic intent," but only 119 of these suggested NSAID-related gastroprotection as a reason for the prescription. ${ }^{57}$ 
Medlock, S., Eslami, S., Askari, M., Taherzadeh, Z., Opondo, D., Rooij, S.E. de, Abu-Hanna, A. Co-prescription of gastroprotective agents and their efficacy in elderly patients taking nonsteroidal anti-inflammatory drugs: a systematic review of observational studies. Clinica Gastroenterology and Hepatology: 2013, 11(10), 1259-1269

\section{[TABLE 3]}

\section{Side Effects of Gastroprotective Agents}

Only 1 study investigated possible side effects of gastroprotective agents. ${ }^{36}$ This study did not report on which medication (NSAID or the gastroprotective agent) may have caused the side effects.

\section{DISCUSSION}

The risk-adjusted outcomes of the studies in this review are in concordance with data from clinical trials ${ }^{11}$ in high-risk patients, pointing toward the effectiveness of PPIs at preventing GI ulcers in NSAID users. However, the evidence is insufficient to quantify this effect, to advise on which age groups benefit most from gastroprotection, or to estimate what the effect would be if more elderly patients received gastroprotection. A median of $24 \%$ of elderly patients received gastroprotection in the included studies and only increased slightly in the oldest age groups. The studies investigated different clinical outcomes, different NSAIDs and gastroprotective agents, different definitions of a concomitant prescription, and adjusted for different risk factors. Many seniors take gastroprotective agents for GI complaints rather than for gastroprotection, and higher-risk patients are more likely to be taking gastroprotective medication. These factors must be taken into account when assessing the effectiveness and cost-effectiveness of PPIs and other gastroprotective agents in elderly patients.

The rate of co-prescription found in the included studies is similar to the rate reported in a 2006 review $^{62}$ and is only slightly higher than the usage of gastroprotective agents in the population of elderly people who do not use

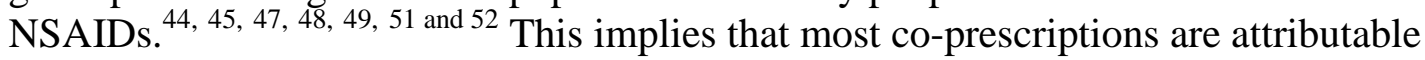
to patients taking gastroprotective agents for other indications, in concordance with the study investigating prescriber's intent. ${ }^{57}$ Prevalent use of PPIs is associated with a higher risk of a GI event ${ }^{39}$; thus, distinguishing incident from prevalent use is important in determining efficacy and predicting efficacy if the rate of coprescription were higher.

Although older age was generally associated with higher rates of co-prescription, results were inconsistent when compared with younger high-risk patients, with 1 study reporting a higher co-prescription rate in younger patients $(79.7 \%$ vs $55.4 \%)^{50}$ and 2 reporting similar rates in both groups. ${ }^{46}$ and 53 Variation in local guideline recommendations (Supplementary Table 1) may impact the rate of coprescription, but if this were the main cause of variation, then we would expect a much higher rate in older seniors (eg, >75 years) for whom gastroprotection is consistently recommended. Instead, we see that the rate of co-prescription was only slightly higher in the oldest age groups.

The 2 included studies assessing cost-effectiveness reached opposing conclusions. This may be due to differences between countries but may also be attributable to calculating cost that is based on the average cost of treating a complicated ulcer $^{56}$ versus the cost of services used by patients with and without coprescription. $^{54}$

We chose to analyze observational data because elderly people appear to be underrepresented in clinical trials, but also because observational data can provide a 
Medlock, S., Eslami, S., Askari, M., Taherzadeh, Z., Opondo, D., Rooij, S.E. de, Abu-Hanna, A. Co-prescription of gastroprotective agents and their efficacy in elderly patients taking nonsteroidal anti-inflammatory drugs: a systematic review of observational studies. Clinic Gastroenterology and Hepatology: 2013, 11(10), 1259-1269

valuable adjunct to trial data. Clinical trials control for comorbidities, interacting medications, and compliance. ${ }^{12}$ By contrast, elderly patients often have comorbidities ${ }^{63}$ and multiple medications, ${ }^{64}$ and patient preference, variation in guidelines, and reimbursement policy ${ }^{65}$ may affect compliance. Observational studies, particularly population-based studies, can represent the complexity of the elderly population to reach conclusions about both efficacy and adverse effects. There are some limitations to our study. It is possible that some relevant studies were missed in the search process. Two researchers independently evaluated the articles for inclusion, but it is possible that examination of the full text of articles excluded on the basis of title and abstract could yield additional studies, particularly those with subgroup analyses of patients older than 65 years. The main limitation is that the small number of studies and heterogeneity prevented quantitative assessment of the effectiveness of gastroprotective agents in preventing NSAID-related GI events. Our review found 7 studies reporting results with the potential to be combined in a metaanalysis (3 reporting both adjusted and unadjusted results, ${ }^{37,38}$ and 392 reporting only adjusted results, ${ }^{54}$ and 55 and 2 reporting only unadjusted results ${ }^{35}$ and 36 ), which took place in only 5 distinct populations. We chose to approach this review by identifying as many relevant studies as possible and then eliminating studies if necessary on the basis of heterogeneity. ${ }^{14}$ To this end, we chose fairly broad inclusion criteria. We chose to include all studies with a population averaging older than 65 years of age. Although an average age of 65 and older does not ensure that the results are applicable to all elderly patients, an average age younger than 65 years virtually ensures that the elderly patients were underrepresented. Therefore, we chose to use this broad criterion, although it could have contributed to heterogeneity by including small studies with a few very old patients skewing the average age. However, no such studies were identified, and 3 relevant studies were included that would have otherwise been missed. ${ }^{52,55}$ and 56 We also chose not to restrict definitions of outcome, definition of exposure (co-prescription), or the baseline risk of the population, because there are not yet any standard definitions, and any chosen set of definitions would be very likely to exclude relevant studies.

Although meta-regression can be used to test and adjust for heterogeneity, a limitation of this approach is that only factors reported by all studies can be used, and the number of variables in the adjustment should not exceed 1 per 5-10 studies. ${ }^{60}$ The studies could also be stratified on the basis of study population (national or regional cohorts, referral center, or general practice populations), type of GI event measured, and type of gastroprotective agent used. All of the included studies focused on the efficacy of PPIs; the use of misoprostol and H2RAs in the elderly also warrant investigation. To address the clinical question of how effective gastroprotection is for elderly patients and at what age patients should receive it, future reporting of observational data should be directed at facilitating comparison with other studies.

\section{Recommendations for Reporting to Facilitate Comparison Between Studies}

To compare results between studies, future studies should attempt to standardize reporting in the areas of heterogeneity identified in the included studies: the choice of outcome measure, the definitions of drug exposure and co-prescription, and assessing differences in baseline risk in treated and untreated patients.

\section{Outcome measure}


Medlock, S., Eslami, S., Askari, M., Taherzadeh, Z., Opondo, D., Rooij, S.E. de, Abu-Hanna, A. Co-prescription of gastroprotective agents and their efficacy in elderly patients taking nonsteroidal anti-inflammatory drugs: a systematic review of observational studies. Clin Gastroenterology and Hepatology: 2013, 11(10), 1259-1269

If possible, multiple outcomes should be assessed. Potentially relevant outcomes include GI events treated on an outpatient basis, hospitalization for GI events, serious/complicated ulcers, and deaths that are due to GI events. Efficacy and costeffectiveness studies should account for a possible difference in the severity of ulcer complications in patients taking gastroprotective agents, which could result in lower treatment costs. Adverse effects from the gastroprotective agents themselves should also be measured: both common side effects such as GI disturbance and the potential for more serious side effects such as increased risk of pneumonia or osteoporosis.

\section{Definition of co-prescription/exposure}

Abraham et $\mathrm{al}^{39}$ demonstrated the importance of the definition of co-prescription in establishing efficacy, showing a 3-fold difference in hazard ratio between patients who had received a gastroprotective agent for $<20 \%$ of the duration of NSAID prescription vs $>80 \%$ of NSAID prescription. A recent study showed similar results, with patients who had discontinued prescriptions for PPIs having a significantly higher chance of a GI event than patients who were still taking a PPI (OR = 1.45). ${ }^{66}$ An estimate of the actual percentage of overlapping duration can be used in analysis of heterogeneity. Incident and prevalent users of gastroprotective agents should be reported separately. Patients already taking gastroprotective agents have a higher baseline risk, ${ }^{38}$ and data from incident users can be used to extrapolate to nonusers. Results should also be reported separately for different classes of gastroprotective agents, and subtherapeutic doses should be excluded.

\section{Difference in baseline risk between treated and untreated patients}

Development and validation of a prediction model for GI events resulting from NSAID use remain a subject for future research. Until such a model is available, researchers can adjust for well-known risk factors and report the difference in risk between the treated and untreated groups. This difference could then be assessed as a source of heterogeneity in future meta-analyses. To establish the influence of age on the effectiveness and need for therapy, results should be reported at least per 5-year age group.

\section{CONCLUSIONS}

The observational evidence for the effectiveness of co-prescription of gastroprotective agents with NSAIDs to prevent GI events in elderly patients is in concordance with the evidence from randomized controlled trials in high-risk patients. All included studies show a substantial benefit to gastroprotection in preventing GI events associated with NSAID therapy in elderly patients. However, the evidence is insufficient to quantify this effect in a meta-analysis, and we cannot extrapolate to determine at what age NSAID treatment should be accompanied by gastroprotective agents and what the effect would be if a higher percentage of elderly patients received gastroprotection. The median rate of co-prescription for patients older than 65 years of age is $24 \%$ in the included studies, and the rate of coprescription for very old patients is only slightly higher. We suggest that future observational studies report results to facilitate future meta-analysis, including a measure of the difference in baseline risk between the treated and untreated patients, and assess the adverse effects as well as the benefits of gastroprotection. 
Medlock, S., Eslami, S., Askari, M., Taherzadeh, Z., Opondo, D., Rooij, S.E. de, Abu-Hanna, A Co-prescription of gastroprotective agents and their efficacy in elderly patients taking nonsteroidal anti-inflammatory drugs: a systematic review of observational studies. Clin Gastroenterology and Hepatology: 2013, 11(10), 1259-1269

\section{SUPPLEMENTARY APPENDIX. DETAILS OF SEARCH}

Database: Embase 1980 to present, Ovid MEDLINE <1946 to week 1, March 2013>

1 antiarthritic.mp [mp = title, abstract, subject headings, heading word, drug trade name, original title, device manufacturer, drug manufacturer, device trade name, keyword] (1109)

2 non steroidal anti inflam*.mp $(24,343)$

3 NSAID*.mp (41881)

4 (elder* or senior*).mp $(441,880)$

5 gastrointestinal.mp $(601,703)$

6 anti-inflammatory agents, non steroidal.mp $(49,907)$

71 or 2 or 3 or $6(92,390)$

8 renal.mp $(1,016,005)$

9 peptic ulcer.mp. or exp Peptic Ulcer/ $(180,392)$

10 gastric ulcer.mp. or exp Stomach Ulcer/ $(60,339)$

11 exp Duodenal Ulcer/ or Duodenal Ulcer.mp. $(58,780)$

125 or 9 or 10 or $11(751,925)$

134 and 7 and 12 (1308)

14 remove duplicates from 13 (875)

15 limit 14 to abstracts (830)

16 limit 15 to English language (687)

17 from 16 keep 1-567 (567)

18 from 17 keep 1-567 (567)

19 gastrointestinal protective.mp (48)

20 gastrointestinal preventive.mp (2)

21 gastroprotective.mp (3220)

22 Histamine 2 blocker.mp (26)

23 proton pump inhibitor*.mp $(32,373)$

24 h2 blocker*.mp (2905)

2519 or 20 or 21 or 22 or 23 or $24(37,616)$

2618 and 25 (141)

27 remove duplicates from 26 (141)

284 and 7 and 25 (312)

29 remove duplicates from 28 (222)

30 limit 29 to abstracts (218)

31 limit 30 to English language (172)

32 ("65 year" or "65 years").mp (100,057)

3332 or $4(517,027)$

3433 and 7 and 25 (411)

35 remove duplicates from 34 (284)

3635 (284)

37 limit 35 to abstracts (280)

38 limit 37 to English language (222) 
Medlock, S., Eslami, S., Askari, M., Taherzadeh, Z., Opondo, D., Rooij, S.E. de, Abu-Hanna, A. Co-prescription of gastroprotective agents and their efficacy in elderly patients taking nonsteroidal anti-inflammatory drugs: a systematic review of observational studies. Clin Gastroenterology and Hepatology: 2013, 11(10), 1259-1269

\section{REFERENCES}

1 C. Sostres, C. Gargallo, A. Lanas Drug-related damage of the ageing gastrointestinal tract Best Pract Res Clin Gastroenterol, 23 (2009), pp. 849-860

2 P. McGettigan, D. Henry Cardiovascular risk with non-steroidal anti-inflammatory drugs: systematic review of population-based controlled observational studies PLoS Med, 8 (2011), p. e1001098

3 A. Pilotto, M. Franceschi, S. Maggi et al. Optimal management of peptic ulcer disease in the elderly Drugs Aging, 27 (2010), pp. 545-558

4 J.H. Wu, Z. Guo, S. Kumar et al. Incidence of serious upper and lower gastrointestinal events in older adults with and without Alzheimer's disease J Am Geriatr Soc, 59 (2011), pp. 2053-2061

5 F.L. Lanza, F.K. Chan, E.M. Quigley Guidelines for prevention of NSAID-related ulcer complications Am J Gastroenterol, 104 (2009), pp. 728-738

6 RAND Corporation Assessing care of vulnerable elders: 3 quality indicators J Am Geriatr Soc, 55 (2007), pp. S464-S487

7 National Institute for Health and Clinical Excellence Osteoarthritis: the care and management of osteoarthritis in adults National Institute for Health and Clinical Excellence, London (2008)

8 Institute for Clinical Systems Improvement Health care guideline: assessment and management of chronic pain Institute for Clinical Systems Improvement, Bloomington, MN (2011)

9 Kwaliteitsinstituut voor de Gezondheidszorg (CBO) Richtlijn NSAID-gebruik en preventie van maagschade CBO, Utrecht (2003)

10 American Geriatrics Society Panel on Pharmacological Management of Persistent Pain in Older Persons Pharmacological management of persistent pain in older persons J Am Geriatr Soc, 57 (2009), pp. 1331-1346

11 A. Rostom, C. Dube, G. Wells et al. Prevention of NSAID-induced gastroduodenal ulcers Cochrane Database Syst Rev (2002), p. CD002296

12 P.M. Rothwell External validity of randomised controlled trials: "to whom do the results of this trial apply?" Lancet, 365 (2005), pp. 82-93

13 S. Eslami, A. Abu-Hanna, N.F. de Keizer et al. Implementing glucose control in intensive care: a multicenter trial using statistical process control Intensive Care Med, 36 (2010), pp. 1556-1565

14 F. Kanwal, D. White Systematic reviews and meta-analyses in Clinical Gastroenterology and Hepatology Clin Gastroenterol Hepatol, 10 (2012), pp. 1184-1186

15 T.J. Brown, L. Hooper, R.A. Elliott et al. A comparison of the cost-effectiveness of five strategies for the prevention of non-steroidal anti-inflammatory drug-induced gastrointestinal toxicity: a systematic review with economic modeling Health Technol Assess, 10 (2006) iii-xiii, 1

16 .W. Yu, S.R. Bauer, P.A. Bain et al. Proton pump inhibitors and risk of fractures: a metaanalysis of 11 international studies Am J Med, 124 (2011), pp. 519-526

17 C.S. Eom, C.Y. Jeon, J.W. Lim et al. Use of acid-suppressive drugs and risk of pneumonia: a systematic review and meta-analysis CMAJ, 183 (2011), pp. 310-319

18 A. Deshpande, C. Pant, V. Pasupuleti et al. Association between proton pump inhibitor therapy and Clostridium difficile infection in a meta-analysis Clin Gastroenterol Hepatol, 10 (2012), pp. 225-233

19 P. Moayyedi, G.I. Leontiadis The risks of PPI therapy Nat Rev Gastroenterol Hepatol, 9 (2012), pp. 132-139

20 College voor Zorgverzekeringen. Farmacotherapeutisch Kompas College voor Zorgverzekeringen, Utrecht (2011) 
Medlock, S., Eslami, S., Askari, M., Taherzadeh, Z., Opondo, D., Rooij, S.E. de, Abu-Hanna, A. Co-prescription of gastroprotective agents and their efficacy in elderly patients taking nonsteroidal anti-inflammatory drugs: a systematic review of observational studies. Clin Gastroenterology and Hepatology: 2013, 11(10), 1259-1269

21 R.M. Leipzig, E.P. Whitlock, T.A. Wolff, US Preventive Services Task Force Geriatric Workgroup et al. reconsidering the approach to prevention recommendations for older adults Ann Intern Med, 153 (2010), pp. 809-814

22 D.M. Zulman, J.B. Sussman, X. Chen et al. Examining the evidence: a systematic review of the inclusion and analysis of older adults in randomized controlled trials J Gen Intern Med, 26 (2011), pp. 783-790

23 A. Lanas, A. Ferrandez Inappropriate prevention of NSAID-induced gastrointestinal events among long-term users in the elderly Drugs Aging, 24 (2007), pp. 121-131

24 S.H. Roth, E.A. Tindall, A.K. Jain et al. A controlled study comparing the effects of nabumetone, ibuprofen, and ibuprofen plus misoprostol on the upper gastrointestinal tract mucosa Arch Intern Med, 153 (1993), pp. 2565-2571

25 S.L. Elliott, N.D. Yeomans, R.R. Buchanan et al. Efficacy of 12 months' misoprostol as prophylaxis against NSAID-induced gastric ulcers: a placebo-controlled trial Scand J Rheumatol, 23 (1994), pp. 171-176

26 F.E. Silverstein, D.Y. Graham, J.R. Senior et al. Misoprostol reduces serious gastrointestinal complications in patients with rheumatoid arthritis receiving nonsteroidal anti-inflammatory drugs: a randomized, double-blind, placebo-controlled trial Ann Intern Med, 123 (1995), pp. 241-249

27 F.K. Chan, J.J. Sung, J.Y. Ching et al. Randomized trial of low-dose misoprostol and naproxen vs nabumetone to prevent recurrent upper gastrointestinal haemorrhage in users of non-steroidal anti-inflammatory drugs Aliment Pharmacol Ther, 15 (2001), pp. 19-24

28 F.K. Chan, L.C. Hung, B.Y. Suen et al. Celecoxib versus diclofenac plus omeprazole in high-risk arthritis patients: results of a randomized double-blind trial Gastroenterology, 127 (2004), pp. 1038-1043

29 K.C. Lai, S.K. Lam, K.M. Chu et al. Lansoprazole reduces ulcer relapse after eradication of Helicobacter pylori in nonsteroidal anti-inflammatory drug users: a randomized trial Aliment Pharmacol Ther, 18 (2003), pp. 829-836

30 J. Concato, N. Shah, R.I. Horwitz Randomized, controlled trials, observational studies, and the hierarchy of research designs N Engl J Med, 342 (2000), pp. 1887-1892

$31 \mathrm{~K}$. Benson, A.J. Hartz A comparison of observational studies and randomized, controlled trials N Engl J Med, 342 (2000), pp. 1878-1886

32 S. Golder, Y.K. Loke, M. Bland Meta-analyses of adverse effects data derived from randomised controlled trials as compared to observational studies: methodological overview PLoS Med, 8 (2011), p. e1001026

33 M. Gamer, J. Lemon, I. Fellows et al. Various coefficients of interrater reliability and agreement R package version 0.83 (2010) [Available at: http://CRAN.Rproject.org/package=irr ]

34 G.H. Guyatt, A.D. Oxman, G. Vist et al. GRADE guidelines: 4-rating the quality of evidence: study limitations (risk of bias) J Clin Epidemiol, 64 (2011), pp. 407-415

35 A. Pilotto, M. Franceschi, M.G. Longoa et al. Helicobacter pylori infection and the prevention of peptic ulcer with proton pump inhibitors in elderly subjects taking low-dose aspirin Dig Liver Dis, 36 (2004), pp. 666-670

36 M.W. van Leen, I. van der Eijk, J.M. Schols Prevention of NSAID gastropathy in elderly patients: an observational study in general practice and nursing homes Age Ageing, 36 (2007), pp. 414-418

37 E. Rahme, A.N. Barkun, Y. Toubouti et al. Do proton-pump inhibitors confer additional gastrointestinal protection in patients given celecoxib? Arthritis Rheum, 57 (2007), pp. 748755 
Medlock, S., Eslami, S., Askari, M., Taherzadeh, Z., Opondo, D., Rooij, S.E. de, Abu-Hanna, A. Co-prescription of gastroprotective agents and their efficacy in elderly patients taking nonsteroidal anti-inflammatory drugs: a systematic review of observational studies. Clin Gastroenterology and Hepatology: 2013, 11(10), 1259-1269

38 E. Rahme, A. Barkun, H. Nedjar et al. Hospitalizations for upper and lower GI events associated with traditional NSAIDs and acetaminophen among the elderly in Quebec, Canada Am J Gastroenterol, 103 (2008), pp. 872-882

39 N.S. Abraham, C. Hartman, D. Castillo et al. Effectiveness of national provider prescription of PPI gastroprotection among elderly NSAID users Am J Gastroenterol, 103 (2008), pp. 323-332

40 F. Clinard, M. Bardou, C. Sgro et al. Non-steroidal anti-inflammatory and cytoprotective drug co-prescription in general practice: a general practitioner-based survey in France Eur J Clin Pharmacol, 57 (2001), pp. 737-743

41 E. Rahme, M.A. Marentette, S.X. Kong et al. Use of NSAIDs, COX-2 inhibitors, and acetaminophen and associated coprescriptions of gastroprotective agents in an elderly population Arthritis Rheum, 47 (2002), pp. 595-602

42 N.R. Hartnell, P.S. Flanagan, N.J. MacKinnon et al. Use of gastrointestinal preventive therapy among elderly persons receiving antiarthritic agents in Nova Scotia, Canada

Am J Geriatr Pharmacother, 2 (2004), pp. 171-180

43 S.E. Gulmez, C. Droz-Perroteau, R. Lassalle et al. CADEUS study group: are traditional NSAIDs prescribed appropriately among French elderly with osteoarthritis? Results from the CADEUS cohort Eur J Clin Pharmacol, 67 (2011), pp. 833-838

44 K.N. van Dijk, K. ter Huurne, C.S. de Vries et al. Prescribing of gastroprotective drugs among elderly NSAID users in The Netherlands Pharm World Sci, 24 (2002), pp. 100-103

45 A. Pilotto, M. Franceschi, G. Leandro et al. Geriatric Gastroenterology Study Group (Societè Italiana Gerontologie Geriatria): NSAID and aspirin use by the elderly in general practice-effect on gastrointestinal symptoms and therapies Drugs Aging, 20 (2003), pp. 701-710

46 N.S. Abraham, H.B. El-Serag, M.L. Johnson et al. National adherence to evidence-based guidelines for the prescription of nonsteroidal anti-inflammatory drugs Gastroenterology, 129 (2005), pp. 1171-1178

$47 \mathrm{~K}$. Johnell, J. Fastbom Concomitant use of gastroprotective drugs among elderly NSAID/COX-2 selective inhibitor users: a nationwide register-based study Clin Drug Investig, 28 (2008), pp. 687-695

48 V.E. Valkhoff, E.M. van Soest, M.C. Sturkenboom et al. Time-trends in gastroprotection with nonsteroidal anti-inflammatory drugs (NSAIDs) Aliment Pharmacol Ther, 31 (2010), pp. 1218-1228

49 B. Superceanu, Z.S. Veldhuyzen van, C. Skedgel et al. The rate of prescribing gastrointestinal prophylaxis with either a proton pump inhibitor or an $\mathrm{H} 2$-receptor antagonist in Nova Scotia seniors starting nonsteroidal anti-inflammatory drug therapy Can J Gastroenterol, 24 (2010), pp. 481-488

50 G. Thiéfin, M.S. Schwalm Underutilization of gastroprotective drugs in patients receiving non-steroidal anti-inflammatory drugs Dig Liver Dis, 43 (2011), pp. 209-214

51 R. Ljung, Y. Lu, J. Lagergren High concomitant use of interacting drugs and low use of gastroprotective drugs among NSAID users in an unselected elderly population: a nationwide register-based study Drugs Aging, 28 (2011), pp. 469-476

52 J.S. Bell, H.T. Taipale, H. Soini et al. Concomitant use of SSRIs, NSAIDs/aspirin and gastroprotective drugs among residents of long-term care facilities: a medical record review Clin Drug Investig, 31 (2011), pp. 337-344

53 S. Morini, A. Zullo, D. Oliveti et al. A very high rate of inappropriate use of gastroprotection for nonsteroidal anti-inflammatory drug therapy in primary care: a crosssectional study J Clin Gastroenterol, 45 (2011), pp. 780-784 
Medlock, S., Eslami, S., Askari, M., Taherzadeh, Z., Opondo, D., Rooij, S.E. de, Abu-Hanna, A Co-prescription of gastroprotective agents and their efficacy in elderly patients taking nonsteroidal anti-inflammatory drugs: a systematic review of observational studies. Clinic Gastroenterology and Hepatology: 2013, 11(10), 1259-1269

54 N.S. Abraham, C. Hartman, J. Hasche Reduced hospitalization cost for upper gastrointestinal events that occur among elderly veterans who are gastroprotected Clin Gastroenterol Hepatol, 8 (2010), pp. 350-356

55 H.E. Vonkeman, R.W. Fernandes, J. van der Palen et al. Proton-pump inhibitors are associated with a reduced risk for bleeding and perforated gastroduodenal ulcers attributable to non-steroidal anti-inflammatory drugs: a nested case-control study Arthritis Res Ther, 9 (2007), p. R52

56 H.E. Vonkeman, L.M. Braakman-Jansen, R.M. Klok et al. Incremental cost effectiveness of proton pump inhibitors for the prevention of non-steroidal anti-inflammatory drug ulcers: a pharmacoeconomic analysis linked to a case-control study Arthritis Res Ther, 10 (2008), p. R144

57 A.M. Dries, P. Richardson, J. Cavazos et al. Therapeutic intent of proton pump inhibitor prescription among elderly nonsteroidal anti-inflammatory drug users Aliment Pharmacol Ther, 30 (2009), pp. 652-661

58 A. Lanas, P. Wu, J. Medin et al. Low doses of acetylsalicylic acid increase risk of gastrointestinal bleeding in a meta-analysis Clin Gastroenterol Hepatol, 9 (2011), pp. 762768

59 M. Egger, G.D. Smith, J.A. Sterne Uses and abuses of meta-analysis Clin Med, 1 (2001), pp. $478-484$

60 J.P.T. Higgins, S. Green (Eds.), Cochrane handbook for systematic reviews of interventions, version 5.1.0, The Cochrane Collaboration (2011) [Available at: http://www.cochrane-handbook.org ]

61 J.A. Sterne, A.J. Sutton, J.P. Ioannidis et al. Recommendations for examining and interpreting funnel plot asymmetry in meta-analyses of randomised controlled trials BMJ, 343 (2011), p. d4002

62 R.A. Moore, S. Derry, C.J. Phillips et al. Nonsteroidal anti-inflammatory drugs (NSAIDs), cyxlooxygenase-2 selective inhibitors (coxibs) and gastrointestinal harm: review of clinical trials and clinical practice BMC Musculoskelet Disord, 7 (2006), p. 79

63 A.A. Uijen, E.H. van de Lisdonk Multimorbidity in primary care: prevalence and trend over the last 20 years Eur J Gen Pract, 14 (Suppl 1) (2008), pp. 28-32

64 M.A. Steinman, J.T. Hanlon Managing medications in clinically complex elders: "There's got to be a happy medium." JAMA, 304 (2010), pp. 1592-1601

65 M.C. Sturkenboom, F. Romano, G. Simon et al. The iatrogenic costs of NSAID therapy: a population study Arthritis Rheum, 47 (2002), pp. 132-140

66 I. Le Ray, A.N. Barkun, F. Vauzelle-Kervroëdan et al. Failure to renew prescriptions for gastroprotective agents to patients on continuous nonsteroidal anti-inflammatory drugs increases rate of upper gastrointestinal injury Clin Gastroenterol Hepatol, 11 (2013), pp. 499-504 
Medlock, S., Eslami, S., Askari, M., Taherzadeh, Z., Opondo, D., Rooij, S.E. de, Abu-Hanna, A. Co-prescription of gastroprotective agents and their efficacy in elderly patients taking nonsteroidal anti-inflammatory drugs: a systematic review of observational studies. Clinicat

FIGURES AND TABLES

Figure 1. Search flow diagram. GPA, gastroprotective agent.

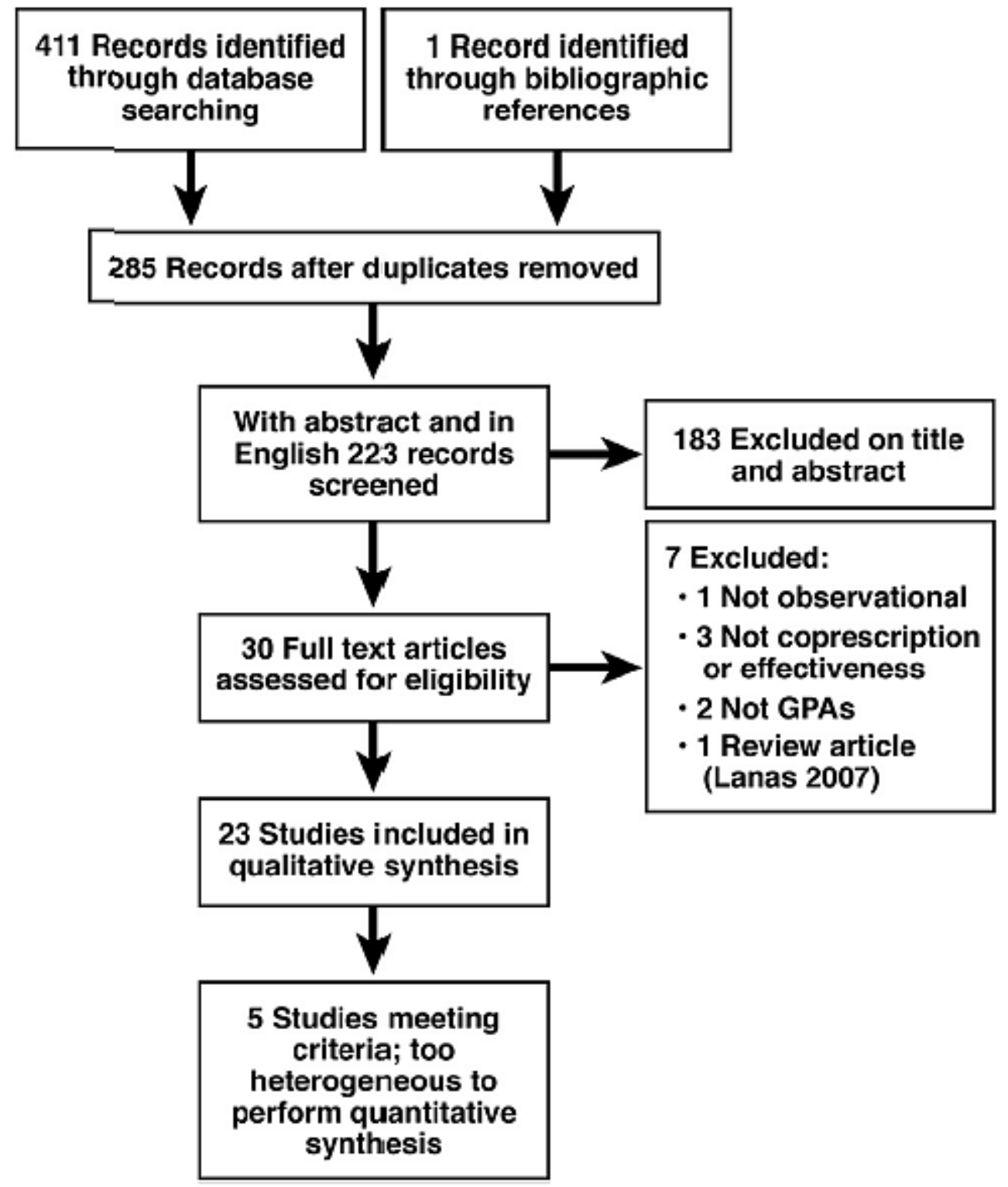


Medlock, S., Eslami, S., Askari, M., Taherzadeh, Z., Opondo, D., Rooij, S.E. de, Abu-Hanna, A. Co-prescription of gastroprotective agents and their efficacy in elderly patients taking nonsteroidal anti-inflammatory drugs: a systematic review of observational studies. Clinicat 7 Gastroenterology and Hepatology: 2013, 11(10), 1259-1269

Table 1. Summary of Included Studies

\begin{tabular}{|c|c|c|c|c|c|}
\hline Study & Size (n) & Setting & Eligibility & Exposure (co-prescription) & Rate of co-prescription $>65 y$ \\
\hline Pilotto, $^{35} 2004$ & 245 & $\begin{array}{l}\text { Italy (referral center); Jan } \\
\text { 1998-Dec } 2001\end{array}$ & $\begin{array}{l}\geq 65 \text { y; using low-dose aspirin; } \\
\text { undergoing endoscopy }\end{array}$ & $\begin{array}{l}\text { NSAID + gastroprotective agent at } \\
\text { time of endoscopy }\end{array}$ & $\begin{array}{l}\text { Low-dose aspirin + PPI: } 20 \% \text { (49/ } \\
245)\end{array}$ \\
\hline van Leen, ${ }^{36} 2007$ & 432 & $\begin{array}{l}\text { Netherlands (national, } \\
\text { participating GPs); Apr } \\
\text { 2003-Mar 2005 }\end{array}$ & $\begin{array}{l}\geq 65 \text { y, general practice; } \\
\text { consecutive patients } \\
\text { prescribed NSAID }\end{array}$ & $\begin{array}{l}\text { Taking NSAID and any } \\
\text { gastroprotective agent; efficacy } \\
\text { measured for pantoprazole }\end{array}$ & $\begin{array}{l}\text { Any NSAID + any gastroprotective } \\
\text { agent: } 37.7 \%(163 / 432)\end{array}$ \\
\hline Rahme, ${ }^{37} 2007$ & 332,491 & $\begin{array}{l}\text { Quebec (regional); Apr 1999- } \\
\text { Dec } 2002\end{array}$ & $\geq 66 \mathrm{y}$, dispensed NSAID & $\begin{array}{l}\text { Dispensed the same day or with } \\
\text { duration that overlapped first day of } \\
\text { NSAID (average overlap 98.5\%) }\end{array}$ & $\begin{array}{l}\text { NS-NSAID + PPI: } 12.1 \%(19,975 / \\
164,934)\end{array}$ \\
\hline Rahme, $^{38} 2008$ & 644,183 & $\begin{array}{l}\text { Quebec (regional); Jan 1998- } \\
\text { Dec } 2004\end{array}$ & $\begin{array}{l}\geq 65 \mathrm{y} \text {, dispensed NSAID, } \\
\text { excluding Gl hospitalization in } \\
\text { last year }\end{array}$ & $\begin{array}{l}\text { Exposure overlapped by any number } \\
\text { of days (exposure }=\text { days } \\
\text { dispensed }+25 \% \text { ) }\end{array}$ & $\begin{array}{l}\text { NS-NSAID + PPI: } 10.2 \%(26,281 / \\
257,312)\end{array}$ \\
\hline Abraham, ${ }^{39} 2008$ & 481,980 & $\begin{array}{l}\text { Veterans' (VA) facilities, USA } \\
\text { (national); Jan 2000-Dec } \\
2002\end{array}$ & 65-99 y, dispensed new NSAID & $\begin{array}{l}\text { Any overlap based on dispensed } \\
\text { doses }\end{array}$ & $\begin{array}{l}\text { NS-NSAID + PPI: } 12.0 \%(53,031 / \\
440,547)\end{array}$ \\
\hline Cinard, ${ }^{40} 2001$ & 791 & $\begin{array}{l}\text { Cote d'Or France (regional, } \\
\text { participating GPs); Apr-Jun } \\
1999\end{array}$ & $\begin{array}{l}\geq 18 \mathrm{y}, \text { general practice; } \\
\text { prescribed new NSAID }\end{array}$ & As reported by the GP & $\begin{array}{l}\text { Any NSAID + gastroprotective agent: } \\
\quad 49.7 \%(79 / 159)\end{array}$ \\
\hline Rahme, $^{41} 2002$ & 70,218 & $\begin{array}{l}\text { Quebec (regional); Apr-Nov } \\
2000\end{array}$ & $\begin{array}{l}\geq 65 \mathrm{y} \text {, dispensed NSAID; random } \\
\text { sample of population }\end{array}$ & Filled on same date & $\begin{array}{l}\text { NS-NSAID + gastroprotective agent: } \\
10.2 \%(840 / 8235)\end{array}$ \\
\hline van Dijk, 2002 & 17,060 & $\begin{array}{l}\text { Netherlands (regional); Jan } \\
\text { 1998-Dec } 1999\end{array}$ & $\geq 65 \mathrm{y}$, prescribed NSAID & $\begin{array}{l}\text { Overlap of at least } 1 \text { day (average of } \\
67 \% \text { overlap); separate analysis } \\
\text { using same physician, same day }\end{array}$ & $\begin{array}{l}\text { Any NSAID + gastroprotective agent: } \\
34.3 \%(2252 / 6557) \text {; any NSAID + } \\
\text { PPl: } 19.2 \%(1262 / 6557)\end{array}$ \\
\hline Pilotto, ${ }^{45} 2003$ & 3154 & $\begin{array}{l}\text { Italy (regional, participating } \\
\text { GPS); Feb-Mar } 1999\end{array}$ & $\begin{array}{c}\geq 65 \text { y, general practice; } \\
\text { consecutive patients }\end{array}$ & $\begin{array}{l}\text { Currently using NSAID and GI } \\
\text { medication (not further specified) }\end{array}$ & $\begin{array}{l}\text { Any NSAID + Gl drug: } 24.0 \% \text { (187/ } \\
779)\end{array}$ \\
\hline Hartnell, ${ }^{42} 2004$ & 14,587 & $\begin{array}{l}\text { Nova Scotia, Canada } \\
\text { (regonal); Jan 2001-Aug } \\
2002\end{array}$ & $\geq 65 \mathrm{y}$, reimbursed NSAIDs & Filled on same date & $\begin{array}{l}\text { NS-NSAID + gastroprotective agent: } \\
14.0 \%(1528 / 10,940)\end{array}$ \\
\hline Abraham, ${ }^{46} 2005$ & $\begin{array}{l}707,244,303,787 \\
\text { high-risk, } 264,679 \\
\geq 65 \text { y }\end{array}$ & $\begin{array}{l}\text { Veterans' (VA) facilities, USA } \\
\text { (national); Jan 2002-Dec } \\
2002\end{array}$ & $\begin{array}{l}18-99 \text { y; using NS-NSAID, aspirin, } \\
\text { or cOX-2 }\end{array}$ & $\begin{array}{l}\text { Overlap of gastroprotective agent with } \\
\text { first NSAID prescription in study } \\
\text { period (index prescription) }\end{array}$ & $\begin{array}{l}\text { NS-NSAID + gastroprotective agent: } \\
23.6 \%(45,540 / 192,743)\end{array}$ \\
\hline Johnell, ${ }^{45} 2008$ & 41,626 & $\begin{array}{l}\text { Sweden (national); Oct-Dec } \\
\quad 2005\end{array}$ & $\geq 75 y$ & Implies overlap by dose & $\begin{array}{l}\text { NS-NSAID + gastroprotective agent: } \\
22.3 \%(9020 / 40,378)\end{array}$ \\
\hline Valkhoff, ${ }^{46} 2010$ & 50,126 & $\begin{array}{l}\text { Netherlands (national); Jan } \\
\text { 1996-Dec } 2006\end{array}$ & $\begin{array}{l}\geq 50 \text { y, general practice; } \\
\text { prescribed new NSAID; no prior } \\
\text { gastroprotective agents }\end{array}$ & Prescribed within 2 days & $\begin{array}{l}\text { Any NSAID + gastroprotective agent + } \\
\text { "high risk": } 14.6 \%(3170 / 21,685)\end{array}$ \\
\hline $\begin{array}{l}\text { Superceaneau, }{ }^{47} \\
\quad 2010\end{array}$ & 105,690 & $\begin{array}{l}\text { Nova Scotia, Canada } \\
\text { (regonal); Apr 1998-Mar } \\
2003\end{array}$ & $\geq 65$ y; reimbursed new NSAID & $\begin{array}{l}\text { Use of both meds in the same month; } \\
\text { or gastroprotective agent } \\
\text { prescribed in the same month as } \\
\text { new NSAID prescription }\end{array}$ & $\begin{array}{l}\text { NS-NSAID + gastroprotective agent: } \\
\text { any month: } 40.1 \%(16,240 / \\
40,511) \text {; first month: } 21.2 \%\end{array}$ \\
\hline Thiéfin, ${ }^{50} 2011$ & $2576(516 \geq 65 y)$ & $\begin{array}{l}\text { France (national, participating } \\
\text { GPs); Jun-Aug } 2006\end{array}$ & $\begin{array}{l}\geq 18 \text { y; general practice; } \\
\text { consecutive patients } \\
\text { prescribed NSAID }\end{array}$ & $\begin{array}{l}\text { GP reported patient was taking both } \\
\text { NSAID and gastroprotective agent }\end{array}$ & $\begin{array}{l}\text { Any NSAID + gastroprotective agent: } \\
55.4 \%(286 / 516)\end{array}$ \\
\hline Gulmez, ${ }^{43} 2011$ & 1851 & $\begin{array}{l}\text { France (national); Aug 2003- } \\
\text { Jul } 2004\end{array}$ & $\begin{array}{l}\geq 65 \mathrm{y} \text {, reimbursed NSAID + } \\
\text { osteoarthritis }\end{array}$ & NR & $\begin{array}{l}\text { Any NSAID + PPI: } 36.82 \%(679 / \\
\text { 1851) }\end{array}$ \\
\hline Ljung $^{51} 2011$ & $\begin{array}{l}1,529,267(257,963 \\
\text { with NSAID) }\end{array}$ & Sweden (national); 2008 & $\geq 65 y ; \geq 1$ NSAID reimbursement & Any time in same year & $\begin{array}{l}\text { Any NSAID + gastroprotective agent: } \\
30.0 \%(377,302 / 25,796) ; \text { any } \\
\text { NSAID + PPI: } 18.5 \%(47,791 / \\
25,796)\end{array}$ \\
\hline Bell, $^{52} 2011$ & 1004 & $\begin{array}{l}\text { Helsinki, Finland (regional, } \\
\text { longterm care); September } \\
2003\end{array}$ & $\begin{array}{l}\text { Residents of long-term care wards } \\
\text { in Helsink, Finland }\end{array}$ & Both medications regularly used & $\begin{array}{l}\text { NS-NSAID + any gastroprotective } \\
\text { agent: } 19.9 \%(76 / 382) ; \text { PPIs } \\
\text { 18.3\%; H2RAs: } 1.6 \%\end{array}$ \\
\hline Morini, ${ }^{53} 2011$ & $869(602 \geq 65 y)$ & $\begin{array}{l}\text { Rome, Italy ( } 58 \text { participating } \\
\text { primary care physicians); } 1 \\
\text { week }\end{array}$ & $\begin{array}{l}\text { Consecutive patients visiting } \\
\text { primary care, taking NSAIDs }>3 \\
\text { times/wk for }>6 \text { mo }\end{array}$ & $\begin{array}{l}\text { NSAID + gastroprotective agent at } \\
\text { time of the visit }\end{array}$ & $\begin{array}{l}\text { Any NSAID + gastroprotective agent: } \\
69.4 \%(418 / 602)\end{array}$ \\
\hline Abraham, ${ }^{54} 2010$ & 3566 & $\begin{array}{l}\text { VA facilities, USA (national); } \\
\text { Jan 2000-Dec } 2004\end{array}$ & $\begin{array}{l}\text { 65- } 99 \text { y, dispensed NSAIDs, had } \\
\text { a Gl event recorded in } \\
\text { database }\end{array}$ & $\begin{array}{l}\text { Any overlap based on dispensed } \\
\text { doses }\end{array}$ & $\begin{array}{l}\text { Any NSAID + Gl event + PPI: 1491/ } \\
\quad 3566\end{array}$ \\
\hline Vonkeman, $^{55} 2007$ & $\begin{array}{l}104 \text { cases }+284 \\
\text { controls }\end{array}$ & $\begin{array}{l}\text { Enschede, Netherlands } \\
\text { (referral center); Nov } \\
\text { 2001-Dec 2003 }\end{array}$ & $\begin{array}{l}\text { Hospitalized with serious ulcer }+ \\
\text { using NSAIDs }\end{array}$ & "Concomitant" & $\begin{array}{l}\text { Any NSAID + gastroprotective agent, } \\
\text { cases: } 26 / 104 \text {; controls: } 106 / 284\end{array}$ \\
\hline Vonkeman, ${ }^{55} 2008$ & Same & Same & Same & Same & Same \\
\hline Dries, ${ }^{57} 2009$ & 1491 & $\begin{array}{l}\text { VA hospitals, Houston, USA } \\
\text { (referral center); Jan 2000- } \\
\text { Dec } 2002\end{array}$ & $\geq 65 \mathrm{y}$, dispensed NSAID + PPI & At least 5 days of overlap & $\begin{array}{l}10 \% \text { of concomitant prescriptions had } \\
\text { NSAID gastroprotection as } \\
\text { indication }\end{array}$ \\
\hline
\end{tabular}

NOTE. Studies are referenced by the last name of the first author and the year of publication. Setting, size, eligibility criteria, reported definition, and rate of prescription of gastroprotective agents in patients taking NSAIDs (co-prescription) for patients $\geq 65$ years. Additional study details can be found in Supplementary Table 3 .

GP, general practitioner; NA, not applicable; NR, not reported. 
Medlock, S., Eslami, S., Askari, M., Taherzadeh, Z., Opondo, D., Rooij, S.E. de, Abu-Hanna, A Co-prescription of gastroprotective agents and their efficacy in elderly patients taking nonsteroidal anti-inflammatory drugs: a systematic review of observational studies. Clinice Gastroenterology and Hepatology: 2013, 11(10), 1259-1269

Figure 2. Reported rates of co-prescription for patients 65 years and older. Each point represents the rate of coprescription reported for patients 65 and older in each study. The point is placed at the middle year of the study, with the line extending to show the years in which the study took place. Larger studies are represented with a larger point (smallest $<1000$ patients, largest $>100,000$ patients).

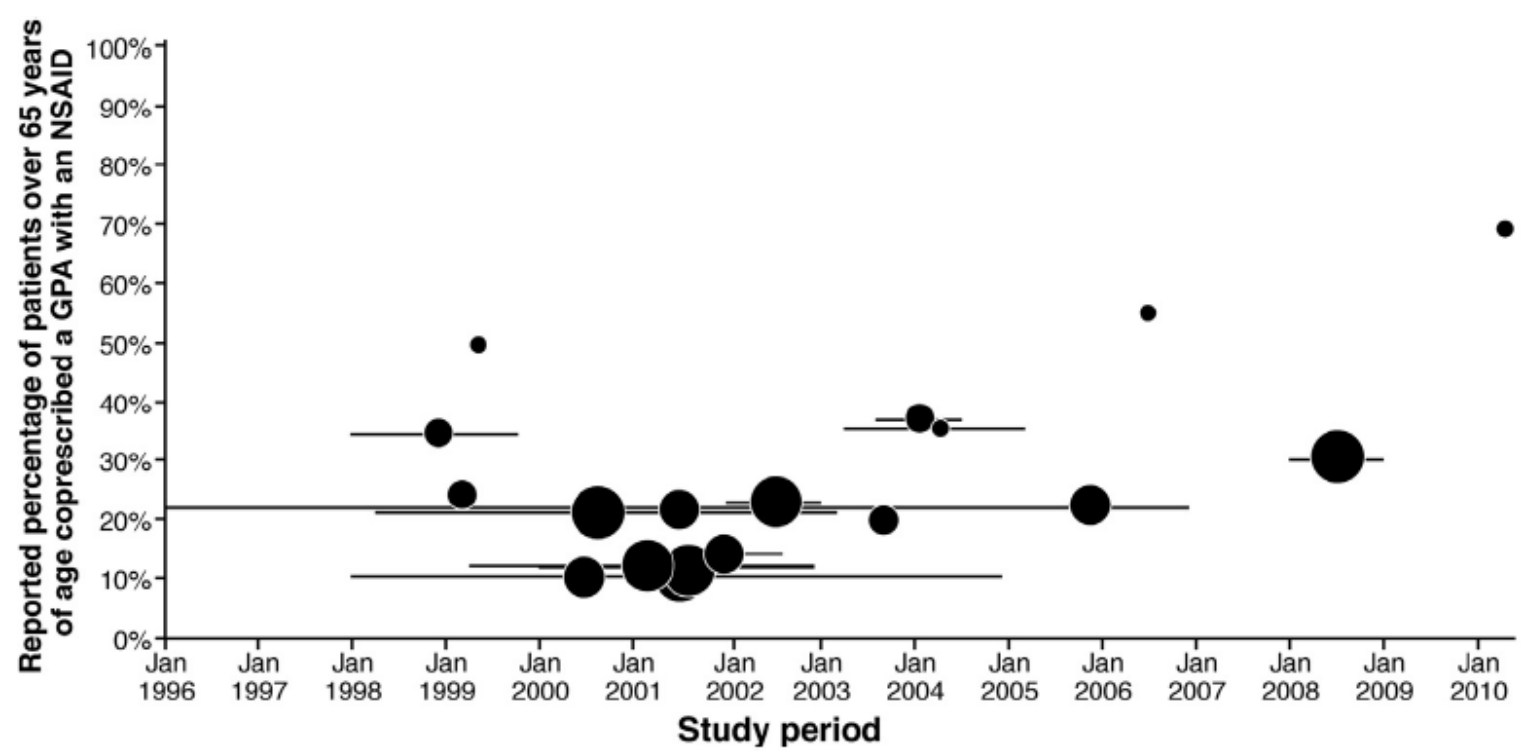


Medlock, S., Eslami, S., Askari, M., Taherzadeh, Z., Opondo, D., Rooij, S.E. de, Abu-Hanna, A. Co-prescription of gastroprotective agents and their efficacy in elderly patients taking nonsteroidal anti-inflammatory drugs: a systematic review of observational studies. Clinicat 7

Gastroenterology and Hepatology: 2013, 11(10), 1259-1269

Table 2. Results From Efficacy Studies

\begin{tabular}{|c|c|c|c|c|c|c|c|}
\hline \multirow[b]{2}{*}{ Study } & \multirow[b]{2}{*}{ Outcome and follow-up } & \multicolumn{2}{|c|}{ With PPI } & \multicolumn{2}{|c|}{ Without PPI } & \multirow[b]{2}{*}{ Reported difference in risk } & \multirow[b]{2}{*}{ Covariates/confounders } \\
\hline & & Events & Total & Events & Total & & \\
\hline van Leen, ${ }^{36} 2007$ & $\begin{array}{l}\text { Gl complaints assessed by survey at } \\
2 \text { wk, } 3 \text { and } 6 \text { mo after visit } \\
\text { Risk of bias: moderate (self-reported) }\end{array}$ & $13^{a}$ & 163 & $107^{a}$ & 269 & NR & Unadjusted \\
\hline Rahme, ${ }^{37} 2007$ & $\begin{array}{l}\text { Unadjusted GI hospitalization rates, } \\
\text { followed through last drug exposure } \\
\text { day or end of study period } \\
\text { Risk of bias: low }\end{array}$ & 33 & 6430 & 301 & 46,192 & $\begin{array}{l}\text { Hazard ratio } \\
\text { NS-NSAIDs vs NS-NSAIDs + PPI: } 2.21 \\
(1.56-3.24)\end{array}$ & $\begin{array}{l}\text { Celecoxib, sex, age, anticoagulants, } \\
\text { corticosteroids, aspirin, anemia, GI } \\
\text { hospitalization in previous } 27 \text { mo, } \\
\text { outpatient diagnosis of ulcer, number of } \\
\text { medications at index date; medication in } \\
\text { prior year for diabetes, hypertension, and } \\
\text { cardiovascular diseases; prescriptions in } \\
\text { prior year for acetaminophen, NSNSAIDs, } \\
\text { and PPI (prior but not concurrent); } \\
\text { diagnoses with cancer and } \\
\text { cerebrovascular disease }\end{array}$ \\
\hline Rahme, $^{38} 2008$ & $\begin{array}{l}\text { Unadjusted GI hospitalization rates, } \\
\text { followed through last drug exposure } \\
\text { day or end of study period } \\
\text { Risk of bias: low }\end{array}$ & 39 & 19,839 & 403 & 91,379 & $\begin{array}{l}\text { Hazard ratio } \\
\text { Referent NS-NSAID without PPI: } \\
\text { All GI hospitalizations } 0.65(0.50-0.85) \\
\text { Upper GI hospitalizations } 0.46(0.33-0.65)\end{array}$ & $\begin{array}{l}\text { Sex, age, number of billings, alcohol, } \\
\text { diagnosis of ulcers, visited a } \\
\text { gastroenterologist, used PPIs in last year, } \\
\text { used other gastroprotective agent, } \\
\text { corticosteroids, osteoarthritis, use of } \\
\text { aspirin, clopidogrel, or anticoagulants }\end{array}$ \\
\hline Abraham, ${ }^{39} 2008$ & $\begin{array}{l}\text { UGIE by ICD code, median follow-up } \\
\text { of } 328 \text { days for patients with event } \\
\text { and } 268 \text { days for patients without } \\
\text { event } \\
\text { Risk of bias: low }\end{array}$ & 406 & 53,031 & 1845 & 387,516 & $\begin{array}{l}\text { Hazard ratio } \\
\text { No exposure as referent: } \\
\text { NSAID alone: } 1.8(1.6-2.0) \\
\text { PPI alone: } 3.1(2.4-4.0) \\
\text { NSAID + PPI: } 1.1(0.7-4.6)\end{array}$ & $\begin{array}{l}\text { Demographics, UGIE risk factors, } \\
\text { comorbidity, prescription channeling (ie, } \\
\text { propensity score), geographic location, } \\
\text { and multiple time-dependent } \\
\text { pharmacologic covariates, including } \\
\text { aspirin, steroids, anticoagulants, } \\
\text { antiplatelets, statins, and selective } \\
\text { serotonin reuptake inhibitors }\end{array}$ \\
\hline Abraham, ${ }^{4} 2010$ & $\begin{array}{l}\text { UGIE by ICD code (cost-effectiveness) } \\
\text { Risk of bias: low }\end{array}$ & NA & NA & NA & NA & $\begin{array}{l}\text { OR } \\
\text { PPI treatment: } 0.7(0.5-0.9)\end{array}$ & $\begin{array}{l}\text { Age, sex, race, Deyo comoridity index, } \\
\text { medications (coxib, anticoagulants, } \\
\text { antiplatelets, statins, steroids), } \\
\text { comoridities (history of UGIE, } \\
\text { gastroesophageal reflux disease) }\end{array}$ \\
\hline $\begin{array}{l}\text { Pilotto, }{ }^{35} 2004 \\
\quad \text { (low-dose aspirin) }\end{array}$ & $\begin{array}{l}\text { Number of ulcers found in endoscopy } \\
\text { patients } \\
\text { Risk of bias: low }\end{array}$ & 3 & 49 & 59 & 196 & $\begin{array}{l}\text { Absolute risk reduction with use of PPI: } \\
\text { Helicobacter pylori positive }-36.2 \\
\quad(-51.2 \text { to }-21.3) \\
H \text { pylori negative }-12.6(-23.9 \text { to }-1.2)\end{array}$ & Unadjusted \\
\hline Vonkeman, ${ }^{55} 2007$ & $\begin{array}{l}\text { Serious NSAID ulcer complications } \\
\text { (case-control) } \\
\text { Risk of bias: low }\end{array}$ & NA & NA & NA & NA & $\begin{array}{l}\text { Adjusted OR } \\
\text { With use of PPI: } 0.33(0.17-0.67)\end{array}$ & $\begin{array}{l}\text { Coumarin, heart failure, acetaminophen, } \\
\text { low-molecular mass heparin } \\
\text { ("final, parsimonious model") }\end{array}$ \\
\hline Vonkeman, $^{56} 2008$ & $\begin{array}{l}\text { Data from Vonkeman } 2007 \\
\text { (cost-effectiveness) }\end{array}$ & & & & & & \\
\hline
\end{tabular}

NOTE. Results from studies of efficacy of gastroprotection for NSAID-related GI events: outcome (type of Gl event), follow-up period, and number of patients with and without GI events, with and without co-prescribed PPI. The difference in risk as reported by the authors is given, and if the risk was adjusted for covariates/confounding variables, those are also reported.

ICD, International Classification of Diseases; NA, not applicable; NR, not reported; UGIE, upper GI event.

${ }^{a}$ Numbers were estimated from information given in the study; precise numbers were not reported.

Figure 3. Unadjusted results from observational studies of efficacy of gastroprotective agents in elderly patients. A forest plot is shown for unadjusted results of the 5 studies reporting numbers of patients taking NSAIDs who had a GI event with and without PPIs (Mantel-Haenszel [M-H] OR, random effects model). The studies were highly heterogeneous (I2 = 97\%), as indicated by minimal overlap of CIs in the graph; thus, the cumulative result is not considered reliable and is not shown. Number of events for van Leen et al36 were estimated from information given in the study.

Study

Outcome

Abraham 08

Pilotto 04

Rahme 07

Rahme 08

van Leen 07
Upper GI event

Ulcers - endoscopy

GI hospitalization

GI hospitalization

Any Gl complaint

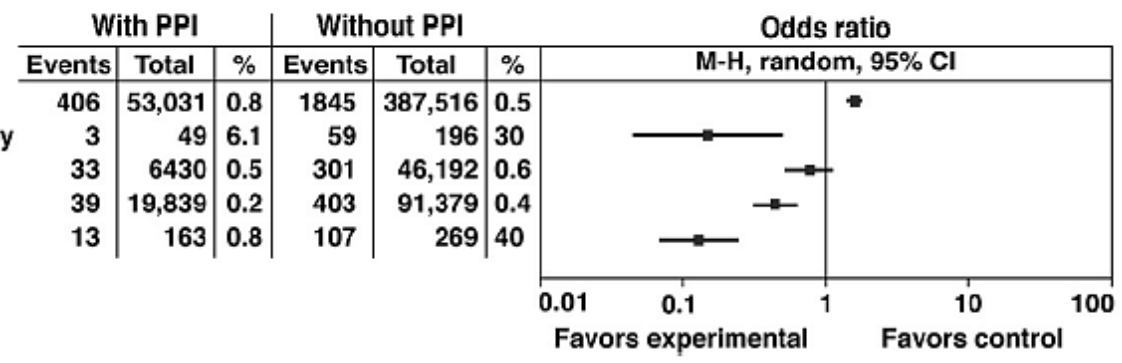


Medlock, S., Eslami, S., Askari, M., Taherzadeh, Z., Opondo, D., Rooij, S.E. de, Abu-Hanna, A. Co-prescription of gastroprotective agents and their efficacy in elderly patients taking nonsteroidal anti-inflammatory drugs: a systematic review of observational studies. Clinica

Gastroenterology and Hepatology: 2013, 11(10), 1259-1269

Table 3. NSAID and Gastroprotective Agent Use Separately and Concomitantly

\begin{tabular}{|c|c|c|c|c|}
\hline Study & NSAID use (\%) & $\begin{array}{l}\text { Gastroprotective agent use } \\
\text { (all elderly) (\%) }\end{array}$ & $\begin{array}{c}\text { Gastroprotective agent use in } \\
\text { non-NSAID users (\%) }\end{array}$ & $\begin{array}{l}\text { Gastroprotective agent use } \\
\text { in NSAID users (\%) }\end{array}$ \\
\hline van Dijk, ${ }^{44} 2002$ & 38.4 & $\begin{array}{l}\text { Gastroprotective agents } 26.6 \\
\text { PPIs } 14.8\end{array}$ & $\begin{array}{l}\text { Gastroprotective agents } 21.8 \\
\text { PPIs } 12.0\end{array}$ & $\begin{array}{l}\text { Gastroprotective agents } 34.3 \\
\text { PPIs } 19.2\end{array}$ \\
\hline Pilotto, ${ }^{45} 2003$ & 24.7 & $\begin{array}{l}\text { Gastroprotective agents } 20.6 \\
\text { PPIs } 3.1\end{array}$ & NR & Gastroprotective agents 24.0 \\
\hline Johnell, ${ }^{47} 2008$ & 5.7 & Gastroprotective agents 13.9 & Gastroprotective agents 13.4 & Gastroprotective agents 22.3 \\
\hline Valkhoff, ${ }^{48} 2010$ & 36.2 & NR & Gastroprotective agents 10.4 & Gastroprotective agents 14.6 \\
\hline Superceanu, ${ }^{49} 2010$ & $\begin{array}{l}\text { Average } 9.9 \text { (NS-NSAIDs } \\
\text { average } 6.3 \text { ) }\end{array}$ & $\begin{array}{l}\text { Gastroprotective agents } \\
\text { average } 18.1 \\
\text { (PPIs average } 3.2 \text { ) }\end{array}$ & NR & Gastroprotective agents 40.1 \\
\hline Ljung, ${ }^{51} 2011$ & 16.9 & PPIs 19.3 & NR & $\begin{array}{l}\text { Gastroprotective agent } 30.0 \\
\text { PPI } 18.5\end{array}$ \\
\hline Bell, $^{52} 2011$ & 25.1 (non-aspirin NS-NSAIDs 4) & 24.0 & $\begin{array}{l}\text { Gastroprotective agents } 21.6 \\
\text { (non-NSAID, non-SSRI } \\
\text { users) } \\
\text { PPIs } 20.5\end{array}$ & $\begin{array}{l}\text { Gastroprotective agent } 19.9 \\
\text { PPI } 18.3\end{array}$ \\
\hline
\end{tabular}

NOTE. In most studies, gastroprotective agent use in non-NSAID users is more than half that of NSAID users, implying that most NSAID users who do take gastroprotective agents do so for indications other than gastroprotection from NSAID-induced GI events. All rates are given as percentage of entire study population.

NR, not reported; SSRI, selective serotonin reuptake inhibitor. 
Supplementary Table 1. Summary of Guideline Recommendations for Use of Gastroprotective Agents for Safer NSAID Prescribing in Older Adults

Guideline

American College of Gastroenterology: Guidelines for prevention of NSAID-related ulcer complications

RAND Corporation: Assessing Care of Vulnerable Elders - 3

National Institute for Health and Clinical Excellence (NICE): Osteoarthritis: The care and management of osteoarthritis in adults

Institute for Clinical Systems Improvement: Assessment and Management of Chronic Pain

Kwaliteitsinstituut voor de Gezondheidszorg (CBO)

American Geriatrics Society Panel on Pharmacological Management of Persistent Pain in Older Persons
Year

2009

Age $>65 \mathrm{y}=$ moderate risk

Patients considered to be at moderate risk can be treated with COX-2 inhibitor alone or NSAID + misoprostol or PPI

Two or more risk factors are in a high-risk category; these patients should also be treated with COX-2 inhibitor and either misoprostol or PPI therapy

2007 If age $\geq 75$ and treated with NS-NSAID, then treat concomitantly with misoprostol or PPI

If 2 or more risk factors and treated with daily aspirin, then treat concomitantly with misoprostol or PPI

2008 When offering treatment with oral NSAID/COX-2 inhibitor, the first choice should be either standard NSAID or COX-2 inhibitor co-prescribed with PPI

2011 All NSAIDs have GI risks of gastritis and possible bleeding. Risk benefits should be weighed, especially when treating elderly patients or those at higher risk for Gl adverse effects. Consider using in combination with gastroprotective agent misoprostol or PPI If age $\geq 70$ or age $\geq 60$ with another risk factor, NS-NSAIDs should be prescribed with PPI

2009 Demographers, insurers, and employers have defined older persons as age 65 and older. By age 75, many persons exhibit some frailty and chronic illness; focused its attention on this older frail population in preparing this update. NS-NSAIDs and COX-2 selective inhibitors may be considered rarely, and with extreme caution, in highly selected individuals. Older persons taking NS-NSAIDs should use PPI or misoprostol for GI protection. Patients taking COX-2 selective inhibitor with aspirin should use PPI or misoprostol for Gl protection (high quality of evidence, strong recommendation)

NOTE. Most guidelines recommend use of a gastroprotective agent, most commonly misoprostol or PPI, for patients older than age of 75 who are using NS-NSAIDs. Some also recommend gastroprotection for younger patients (age 65 and older), especially those with at least 1 additional risk factor. Some also recommend gastroprotection for those taking COX-2 selective NSAIDs as well as NSNSAIDs. 
Supplementary Table 2. Details of Randomized Controlled Trials Included in Cochrane Review With a Population Aged 65 Years or Older

$$
\text { Study }
$$

Population

Eligibility criteria

Conclusion

Roth SH, Tindall EA, Jain AK, et al. A Compare nabumetone, ibuprofen, and 148 patients aged 60 and older with controlled study comparing the effects of nabumetone, ibuprofen, and ibuprofen plus misoprostol on the upper gastrointestinal tract mucosa. Arch Intern Med 1993;153:2565-2571

Chan FK, Sung JJ, Ching JY, et al. Randomized trial of low-dose misoprostol and naproxen vs nabumetone to prevent recurrent upper gastrointestinal

haemorrhage in users of nonsteroidal anti-inflammatory drugs. Aliment Pharmacol Ther 2001;15:19-24

Elliott SL, Yeomans ND, Buchanan RR, Determine long-term effect of et al. Efficacy of 12 months' misoprostol as prophylaxis against NSAID-induced gastric ulcers: a placebo-controlled trial. Scand J Rheumatol 1994;23:171-176. ibuprofen + misoprostol on endoscopically diagnosed ulcers at 2,6 , and 12 weeks after start of study

Compare nabumetone vs naproxen with low-dose misoprostol for secondary prevention of recurrent upper Gl bleeding or major $\mathrm{Gl}$ events in 24 weeks

misoprostol on development of gastric ulcers and erosions in NSAID users during a 12-month period osteoarthritis. Included patients of the following ages: nabumetone: 15 (60-64), 34 (65-74), 9 (>75); ibuprofen: 17 (60-64), 32 (65-74), 4 ( $\geq 75)$; ibuprofen + misoprostol: 22 (60-64), 35 (65-74), 3 ( $\geq 75)$

steoarthritis functional class 2 or 3

acetaminophen was allowed

90 patients presenting with upper Gl Presenting with bleeding peptic ulcers Misoprostol + naproxen is equivalent bleeding and requiring NSAID

therapy. Median age of

misoprostol/naproxen group $=75$

(range, 43-92); median age of

nabumetone group $=74$ (range

42-89)

83 patients with chronic rheumatic disorders on NSAIDs for at least 3 mo. Mean age placebo group, $66 \mathrm{y}$ (standard deviation \pm 11.5 ); misoprostol group, 65 years $( \pm 6.5)$ used NSAIDs for at least 3 mo

before enrollment and expected to

continue this medication for at least

3 mo. Excluded patients with

history of allergy to study

medications, intolerance of

ibuprofen, heart disease, history of

Gl disease in last year, use of

steroids, anticoagulants,

immunosuppressives, or ulcer

therapy; or patients prescribed

multiple NSAIDs or joint

replacement. Co-medication with

and had taken NSAIDs within 7

days; inadequate pain relief from

simple analgesics; negative for $H$

pylori; gave informed written

consent. Excluded patients taking

acid suppressive drugs, steroids,

anticoagulants, aspirin; history of

gastric surgery, concurrent upper GI

diseases, history of treatment for $H$

pylori; renal impairment,

malignancy, or unable to return for follow-up

abumetone is equivalent to

ibuprofen + misoprostol and

significantly less ulcerogenic than

ibuprofen alone

to nabumetone for secondary

prevention of upper Gl bleeding.

Neither regimen is adequate in

high-risk patients

der than 18 years of age, on stable oral NSAID therapy, attending arthritis clinics for chronic patients with overt upper Gl

hemorrhage within the last month, inflammatory bowel disease or chronic diarrhea, malignancy, or taking any other antiulcer drugs rheumatic disorders. Excluded
Misoprostol decreases cumulative risk of NSAID-induced gastric ulcers 


\begin{tabular}{|c|c|c|c|c|}
\hline Study & Objective & Population & Eligibility criteria & Conclusion \\
\hline $\begin{array}{l}\text { Silverstein FE, Graham DY, Senior JR, } \\
\text { et al. Misoprostol reduces serious } \\
\text { gastrointestinal complications in } \\
\text { patients with rheumatoid arthritis } \\
\text { receiving nonsteroidal anti- } \\
\text { inflammatory drugs: a randomized, } \\
\text { double-blind, placebo-controlled } \\
\text { trial. Ann Intern Med } \\
\text { 1995;123:241-249 }\end{array}$ & $\begin{array}{l}\text { Determine whether misoprostol } \\
\text { decreases the incidence of serious } \\
\text { upper Gl complications in older } \\
\text { patients with chronic rheumatoid } \\
\text { arthritis taking NSAIDs by using } \\
\text { clinical/symptomatic diagnosis }\end{array}$ & $\begin{array}{l}8843 \text { patients } 52 \text { y of age and older } \\
\text { with chronic rheumatoid arthritis } \\
\text { and taking NSAIDs for at least } 6 \\
\text { mo. Misoprostol: } 6(<52), 349 \\
\text { (52-59), } 1192(60-64), 1231 \\
\text { (65-69), } 929(70-74), 695(\geq 75) \text {; } \\
\text { placebo: } 6(<52), 347(52-59), \\
1222(60-64), 1254(65-69), 884 \\
(70-74), 724(\geq 75)\end{array}$ & $\begin{array}{l}\text { At least } 52 \text { years of age, with chronic } \\
\text { rheumatoid arthritis, taking } 1 \text { of } 10 \\
\text { NSAIDs at predefined minimum } \\
\text { dose for at least } 6 \text { months. } \\
\text { Excluded if they had had active } \\
\text { peptic ulcer disease, not taking or } \\
\text { needing antiulcer medication, } \\
\text { enrolled in other medication } \\
\text { studies, history of various GI } \\
\text { diseases, malignancy, alcoholism, } \\
\text { hepatitis, bleeding disorders, poor } \\
\text { prognosis, or intolerance to } \\
\text { misoprostol. Patients taking } \\
\text { multiple NSAIDs were included }\end{array}$ & $\begin{array}{l}\text { Misoprostol significantly reduces } \\
\text { incidence of NSAID-induced, } \\
\text { serious upper GI complications, } \\
\text { including perforation, obstruction, } \\
\text { and bleeding, in older patients with } \\
\text { rheumatoid arthritis }\end{array}$ \\
\hline $\begin{array}{l}\text { Chan FK, Hung LC, Suen BY, et al. } \\
\text { Celecoxib versus diclofenac plus } \\
\text { omeprazole in high-risk arthritis } \\
\text { patients: results of a randomized } \\
\text { double-blind trial. Gastroenterology } \\
\text { 2004;127:1038-1043 }\end{array}$ & $\begin{array}{l}\text { Compare celecoxib with diclofenac }+ \\
\text { omeprazole in patients with } \\
\text { arthritis and prior ulcers for } \\
\text { incidence of recurrent clinical Gl } \\
\text { complications or endoscopically } \\
\text { diagnosed gastric or duodenal ulcer }\end{array}$ & $\begin{array}{l}287 \text { patients with arthritis presenting } \\
\text { with bleeding ulcer while receiving } \\
\text { NSAIDs. Mean age celecoxib group, } \\
65.3 \text { years (standard deviation } \pm \\
\text { 14.6); diclofenac }+ \text { omeprazole } \\
\text { group, } 68 \text { years }( \pm 12.8 \text { ) }\end{array}$ & $\begin{array}{l}\text { Confirmed healed ulcer, no } \mathrm{H} \text { pylori or } \\
\text { successful treatment for } \mathrm{H} \text { pylori, } \\
\text { anticipated regular use of NSAIDs. } \\
\text { Excluded patients taking } \\
\text { anticoagulants, corticosteroids; } \\
\text { history of gastric or duodenal } \\
\text { surgery except a patch repair; } \\
\text { erosive esophagitis or gastric outlet } \\
\text { obstruction; renal failure, terminal } \\
\text { illness, or cancer }\end{array}$ & $\begin{array}{l}\text { Neither therapy was adequate to } \\
\text { prevent reoccurrence. Treatment- } \\
\text { induced dyspepsia is an indication } \\
\text { for further investigation }\end{array}$ \\
\hline $\begin{array}{l}\text { Lai KC, Lam SK, Chu KM, et al. } \\
\text { Lansoprazole reduces ulcer relapse } \\
\text { after eradication of Helicobacter } \\
\text { pylori in nonsteroidal anti- } \\
\text { inflammatory drug users: a } \\
\text { randomized trial. Aliment } \\
\text { Pharmacol Ther 2003;18:829-836 }\end{array}$ & $\begin{array}{l}\text { Effect of lansoprazole on reoccurrence } \\
\text { of ulcers in patients using NSAIDs } \\
\text { with history of peptic ulcers and } \\
\text { Helicobacter pylori eradication }\end{array}$ & $\begin{array}{l}45 \text { patients with recent history of } \\
\text { endoscopically diagnosed } \\
\text { gastroduodenal ulcers with } H \text { pylori } \\
\text { infection and taking NSAIDs for at } \\
\text { least } 3 \text { mo. Mean age lansoprazole, } \\
67.1 \text { y (range, } 41-78) \text {; no } \\
\text { treatment }(H \text { pylori eradication } \\
\text { only), } 70.2 \text { y (43-78). Older than } \\
65 \text { y: lansoprazole, } 13 \text { (59.1\%); } \\
\text { control, } 12(57.1 \%)\end{array}$ & $\begin{array}{l}\text { Age } 18-80 \text { years with recent } \\
\text { endoscopically diagnosed } \\
\text { gastroduodenal ulcers with H pylori } \\
\text { infection and taking NSAID } \\
\text { (excluding aspirin) for at least } 3 \text { mo. } \\
\text { Excluded patients with esophageal } \\
\text { ulcers, pyloric obstruction, erosive } \\
\text { esophagitis, previous treatment for } \\
\text { H pylori; taking antibiotics, bismuth } \\
\text { compounds, sucralfate, PPIs, } \\
\text { anticoagulants, or corticosteroids; } \\
\text { previous gastric resective surgery, } \\
\text { allergy to the study drugs, or major } \\
\text { organ failure }\end{array}$ & $\begin{array}{l}\text { Lansoprazole was significantly better } \\
\text { than } \mathrm{H} \text { pylori eradication alone in } \\
\text { preventing relapse of ulcerative } \\
\text { disease }\end{array}$ \\
\hline
\end{tabular}

NOTE. Six of 39 studies included in the Cochrane review of the efficacy of gastroprotective agents in preventing NSAID-related ulcers included a population with an average age of 65 years or older. Further details of these studies, as well as details of other 33 studies including mean/median age of participants, can be found in the Cochrane review. 


\begin{tabular}{|c|c|c|c|c|c|c|c|c|}
\hline Study & Setting & Objective & Eligibility & NSAID exposure & $\begin{array}{c}\text { Gastroprotective agent } \\
\text { exposure }\end{array}$ & $\begin{array}{l}\text { Concomitant/ } \\
\text { co-prescription }\end{array}$ & Sensitivity analysis & $\begin{array}{l}\text { Outcomes measured/ } \\
\text { conclusion }\end{array}$ \\
\hline \multicolumn{9}{|c|}{ Co-prescription + efficacy } \\
\hline Pilotto 2004 & $\begin{array}{l}\text { Italy; Jan 1998-Dec } \\
\quad 2001\end{array}$ & $\begin{array}{l}\text { Evaluate relationship } \\
\text { between use of low- } \\
\text { dose aspirin, } \\
\text { Helicobacter pylori, } \\
\text { and use of PPIs in } \\
\text { gastroduodenal } \\
\text { lesions }\end{array}$ & $\begin{array}{l}\geq 65 \mathrm{y} \text {; users of chronic } \\
\text { low-dose aspirin } \\
\text { undergoing } \\
\text { endoscopy (excluded } \\
\text { those taking other } \\
\text { NSAIDs) }\end{array}$ & $\begin{array}{l}\text { Self-reported aspirin } \\
75-300 \mathrm{mg} / \text { day for } \\
\text { at least } 3 \mathrm{mo} \text { before } \\
\text { endoscopy (including } \\
\text { OTC); prevalent use }\end{array}$ & $\begin{array}{l}\text { Omeprazole } 20 \mathrm{mg} / \text { day, } \\
\text { lansoprazole } 30 \mathrm{mg} / \\
\text { day, or pantoprazole } \\
40 \mathrm{mg} / \text { day for at } \\
\text { least } 7 \text { days before } \\
\text { endoscopy }\end{array}$ & $\begin{array}{l}\text { Taking both medications } \\
\text { at time of endoscopy }\end{array}$ & NR & $\begin{array}{l}\text { Number of ulcers found } \\
\text { in endoscopy } \\
\text { patients/H pylori } \\
\text { infection may } \\
\text { influence cost- } \\
\text { effectiveness of PPI } \\
\text { therapy }\end{array}$ \\
\hline van Leen 2007 & $\begin{array}{l}\text { Netherlands; Apr 2003- } \\
\quad \text { Mar } 2005\end{array}$ & $\begin{array}{l}\text { Assess risk factors for } \\
\text { upper Gl events; } \\
\text { assess guideline } \\
\text { compliance; assess } \\
\text { influence and safety } \\
\text { of pantoprazole }\end{array}$ & $\begin{array}{l}\geq 65 \mathrm{y} \text {; consecutive } \\
\text { patients visiting a } \\
\text { general practitioner } \\
\text { and prescribed } \\
\text { NSAID }\end{array}$ & $\begin{array}{l}\text { Self-reported NSAID, } \\
\text { probably includes } \\
\text { OTC; incident and } \\
\text { prevalent use } \\
\text { reported separately }\end{array}$ & $\begin{array}{l}\text { Any gastroprotective } \\
\text { agent at time of } \\
\text { interview (probably } \\
\text { incident and } \\
\text { prevalent) }\end{array}$ & $\begin{array}{l}\text { Already taking NSAID and } \\
\text { gastroprotective agent } \\
\text { (not further specified) }\end{array}$ & NR & $\begin{array}{l}\text { Self-reported Gl } \\
\text { complaints; asked } \\
\text { about adverse } \\
\text { effects/pantoprazole } \\
\text { was effective in } \\
\text { diminishing Gl } \\
\text { complaints }\end{array}$ \\
\hline Rahme 2007 & $\begin{array}{l}\text { Quebec; Apr 1999-Dec } \\
\quad 2002\end{array}$ & $\begin{array}{l}\text { Compare GI } \\
\text { hospitalization rates } \\
\text { in patients taking } \\
\text { coxibs and NS- } \\
\text { NSAIDs with and } \\
\text { without PPI }\end{array}$ & $\begin{array}{l}\geq 66 \text { y; dispensed } \\
\text { NSAID; population- } \\
\text { based }\end{array}$ & $\begin{array}{l}\text { At least } 1 \text { dispensed } \\
\text { prescription of NS- } \\
\text { NSAIDs or celecoxib } \\
>3 \text { days (incident } \\
\text { and prevalent); } \\
\text { estimate that } 46.3 \% \\
\text { of acetaminophen, } \\
17 \% \text { of NS-NSAIDs, } \\
2.2 \% \text { of aspirin are } \\
\text { OTC }\end{array}$ & $\begin{array}{l}\text { PPI dispensed same day } \\
\text { as NSAID or earlier } \\
\text { (incident and } \\
\text { prevalent); estimate } \\
\text { that } 1.1 \% \text { of } \\
\text { gastroprotective } \\
\text { agents are OTC }\end{array}$ & $\begin{array}{l}\text { Dispensed same day or } \\
\text { with duration that } \\
\text { overlapped first day of } \\
\text { NSAID (average overlap } \\
98.5 \% \text { ) }\end{array}$ & Yes & $\begin{array}{l}\text { Unadjusted Gl } \\
\text { hospitalization rates/ } \\
\text { addition of PPI to } \\
\text { celecoxib conferred } \\
\text { extra protection for } \\
\text { patients ages }>75 \text { y. } \\
\text { PPI did not seem } \\
\text { necessary with } \\
\text { celecoxib for patients } \\
\text { ages } 66-74 \text { y }\end{array}$ \\
\hline Rahme 2008 & $\begin{array}{l}\text { Quebec; Jan 1998-Dec } \\
\quad 2004\end{array}$ & $\begin{array}{l}\text { Compare GI } \\
\text { hospitalization rates } \\
\text { in patients taking NS- } \\
\text { NSAIDs/ } \\
\text { acetaminophen with } \\
\text { and without PPI }\end{array}$ & $\begin{array}{l}\geq 65 \mathrm{y} \text {; dispensed } \\
\text { NSAID, excluding GI } \\
\text { hospitalization in last } \\
\text { year; population- } \\
\text { based }\end{array}$ & $\begin{array}{l}\text { At least } 1 \text { dispensed } \\
\text { prescription of NS- } \\
\text { NSAIDs or } \\
\text { acetaminophen } \\
\text { (incident and } \\
\text { prevalent); estimate } \\
\text { that } 46.3 \% \text { of } \\
\text { acetaminophen, 17\% } \\
\text { of NS-NSAIDs, 2.2\% } \\
\text { of aspirin are OTC }\end{array}$ & $\begin{array}{l}\text { At least } 1 \text { dispensed } \\
\text { prescription of PPls } \\
\text { (incident and } \\
\text { prevalent); estimate } \\
\text { that } 1.1 \% \text { of } \\
\text { gastroprotective } \\
\text { agents are OTC }\end{array}$ & $\begin{array}{l}\text { Exposure overlapped by } \\
\text { any number of days } \\
\text { (exposure }=\text { days } \\
\text { dispensed }+25 \%)\end{array}$ & Previously published & $\begin{array}{l}\text { Unadjusted GI } \\
\text { hospitalization rates/ } \\
\text { use of combination of } \\
\text { traditional NSAID and } \\
\text { acetaminophen may } \\
\text { increase risk of GI } \\
\text { bleeding compared } \\
\text { with either agent } \\
\text { alone }\end{array}$ \\
\hline
\end{tabular}


Supplementary Table 3. Continued

\begin{tabular}{|c|c|c|c|c|c|c|c|c|}
\hline Study & Setting & Objective & Eligibility & NSAID exposure & $\begin{array}{l}\text { Gastroprotective agent } \\
\text { exposure }\end{array}$ & $\begin{array}{l}\text { Concomitant/ } \\
\text { co-prescription }\end{array}$ & Sensitivity analysis & $\begin{array}{l}\text { Outcomes measured/ } \\
\text { conclusion }\end{array}$ \\
\hline Abraham 2008 & $\begin{array}{l}\text { Veterans' (VA) facilities, } \\
\text { USA; Jan 2000-Dec } \\
2002\end{array}$ & $\begin{array}{l}\text { Quantify the effect of } \\
\text { provider adherence } \\
\text { on the risk of NSAID- } \\
\text { related upper GI } \\
\text { events }\end{array}$ & $\begin{array}{l}\text { 65-99 y; dispensed new } \\
\text { NSAID; population- } \\
\text { based }\end{array}$ & $\begin{array}{l}\text { Dispensed aspirin }>325 \\
\text { mg/day, salsalate, } \\
\text { diclofenac, diflunisal, } \\
\text { etodolac, fenoprofen, } \\
\text { flurbiprofen, } \\
\text { ibuprofen, } \\
\text { indomethacin, } \\
\text { ketoprofen, } \\
\text { ketorolac, } \\
\text { meclofenamate, } \\
\text { meloxicam, } \\
\text { nabumetone, } \\
\text { naproxen, oxaprozin, } \\
\text { phenylbutazone, } \\
\text { piroxicam, sulindac, } \\
\text { tolmetin, rofecoxib, } \\
\text { valdecoxib, or } \\
\text { celecoxib (full doses); } \\
>5 \text { days, incident } \\
\text { users (none in last } 6 \\
\text { mo). Cannot assess } \\
\text { OTC }\end{array}$ & $\begin{array}{l}\text { Dispensed } \\
\quad \text { esomeprazole, } \\
\text { lansoprazole, } \\
\text { omeprazole, } \\
\text { pantoprazole, or } \\
\text { rabeprazole at } \\
\text { therapeutic doses } \\
\text { (incident and } \\
\text { prevalent). Cannot } \\
\text { assess OTC, only low- } \\
\text { dose H2RA available }\end{array}$ & $\begin{array}{l}\text { Any overlap based on } \\
\text { dispensed doses }\end{array}$ & Yes & $\begin{array}{l}\text { UGIE by ICD code/ } \\
\text { adherence to safer } \\
\text { NSAID prescribing } \\
\text { strategies is } \\
\text { associated with fewer } \\
\text { UGIEs among elderly } \\
\text { patients. An adherent } \\
\text { strategy lowers, but } \\
\text { does not eliminate, } \\
\text { risk of NSAID-related } \\
\text { UGIE }\end{array}$ \\
\hline \multicolumn{9}{|l|}{ Co-prescription } \\
\hline Clinard 2001 & $\begin{array}{l}\text { Cote d'Or France; Apr- } \\
\text { Jun } 1999\end{array}$ & $\begin{array}{l}\text { Assess determinants of } \\
\text { prescribing } \\
\text { gastroprotective } \\
\text { agents }\end{array}$ & $\begin{array}{l}\geq 18 \text { y; visiting GP and } \\
\text { prescribed new } \\
\text { NSAID }\end{array}$ & $\begin{array}{l}\text { GP-reported new } \\
\text { prescription of any } \\
\text { NSAID (incident) }\end{array}$ & $\begin{array}{l}\text { GP reported co- } \\
\text { prescription of any } \\
\text { gastroprotective } \\
\text { agent (incident) }\end{array}$ & As reported by the GP & NA & $\begin{array}{l}\text { Inadequate NSAID } \\
\text { prescription practices } \\
\text { remain relatively } \\
\text { frequent with regard } \\
\text { to elderly patients }\end{array}$ \\
\hline Rahme 2002 & Quebec; Apr-Nov 2000 & $\begin{array}{l}\text { Compare use of COX-2, } \\
\text { NS-NSAIDs, and } \\
\text { gastroprotective co- } \\
\text { prescriptions }\end{array}$ & $\begin{array}{l}\geq 65 \mathrm{y} \text {; dispensed } \\
\text { NSAID; random } \\
\text { sample of population }\end{array}$ & $\begin{array}{l}\text { At least } 1 \text { dispensed } \\
\text { prescription of NS- } \\
\text { NSAIDs, coxib, or } \\
\text { acetaminophen, } \\
\text { analyzed incident } \\
\text { patients separately; } \\
\text { estimate that } 46.3 \% \\
\text { of acetaminophen, } \\
17 \% \text { of NS-NSAIDs, } \\
2.2 \% \text { of aspirin are } \\
\text { OTC }\end{array}$ & $\begin{array}{l}\text { NR; estimate that } 1.1 \% \\
\text { of gastroprotective } \\
\text { agents are OTC }\end{array}$ & Filled on same date & NR & $\begin{array}{l}\text { Adjusted ORs showed } \\
47 \% \text { decrease in } \\
\text { gastroprotective } \\
\text { agent co- } \\
\text { prescriptions with } \\
\text { COX-2 inhibitors } \\
\text { compared with } \\
\text { NSAIDs }\end{array}$ \\
\hline van Dijk 2002 & $\begin{array}{l}\text { Netherlands; Jan 1998- } \\
\quad \text { Dec } 1999\end{array}$ & $\begin{array}{l}\text { Investigate whether co- } \\
\text { prescribing } \\
\text { recommendations } \\
\text { are being followed }\end{array}$ & $\begin{array}{l}\geq 65 \text { y; prescribed } \\
\text { NSAID; population- } \\
\text { based }\end{array}$ & $\begin{array}{l}\text { ATC code M01A, } \\
\text { excluding drugs } \\
\text { prescribed to }<50 \\
\text { people (incident and } \\
\text { prevalent) }\end{array}$ & $\begin{array}{l}\text { Misoprostol, H2RAs, } \\
\text { PPIs (incident and } \\
\text { prevalent) }\end{array}$ & $\begin{array}{l}\text { Overlap of at least } 1 \text { day } \\
\text { (average of } 67 \% \\
\text { overlap), separate } \\
\text { analysis with both } \\
\text { drugs prescribed by } \\
\text { same physician on } \\
\text { same day }\end{array}$ & $\begin{array}{l}\text { Performed } 2 \text { analyses } \\
\text { using different } \\
\text { definitions of co- } \\
\text { prescription }\end{array}$ & $\begin{array}{l}\text { Rate of concomitant } \\
\text { prescribing of } \\
\text { gastroprotective } \\
\text { agents in NSAID } \\
\text { users aged } 65 \text { y and } \\
\text { older is low }\end{array}$ \\
\hline
\end{tabular}


Supplementary Table 3. Continued

\begin{tabular}{|c|c|c|c|c|c|c|c|c|}
\hline Study & Setting & Objective & Eligibility & NSAID exposure & $\begin{array}{l}\text { Gastroprotective agent } \\
\text { exposure }\end{array}$ & $\begin{array}{l}\text { Concomitant/ } \\
\text { co-prescription }\end{array}$ & Sensitivity analysis & $\begin{array}{c}\text { Outcomes measured/ } \\
\text { conclusion }\end{array}$ \\
\hline Pilotto 2003 & Italy; Feb-Mar 1999 & $\begin{array}{l}\text { Identify prevalence of } \\
\text { medication use and } \\
\text { association between } \\
\text { Gl symptoms and } \\
\text { therapies }\end{array}$ & $\begin{array}{l}\geq 65 \text { y; visiting GP with } \\
\text { medical problem }\end{array}$ & $\begin{array}{l}\text { Self-reported use of ATC } \\
\text { M01; differentiated } \\
\text { occasional, acute (7- } \\
30 \text { days), or chronic } \\
\text { ( }>30 \text { days) use; } \\
\text { differentiated low- } \\
\text { dose ( }<300 \mathrm{mg} / \text { day) } \\
\text { and high-dose } \\
\text { aspirin; (prevalent } \\
\text { use); probably } \\
\text { includes OTC }\end{array}$ & $\begin{array}{l}\text { Self-reported use of } \\
\text { antacids, H2 } \\
\text { antagonists, PPIs, } \\
\text { sucralfate, } \\
\text { misoprostol, or } \\
\text { prokinetics for } \\
\text { preceding } 7 \text { days or } \\
\text { more (prevalent use); } \\
\text { probably includes } \\
\text { OTC }\end{array}$ & NR & $\mathrm{NR}$ & $\begin{array}{l}\text { Use of NSAIDs/aspirin } \\
\text { was significantly } \\
\text { associated with } \\
\text { greater number of } \\
\text { upper Gl symptoms } \\
\text { and prescriptions for } \\
\text { Gl drugs }\end{array}$ \\
\hline Hartnell 2004 & $\begin{array}{l}\text { Nova Scotia, Canada; } \\
\quad \text { Jan 2001-Aug } 2002\end{array}$ & $\begin{array}{l}\text { Assess use of } \\
\text { gastroprotective } \\
\text { agents }\end{array}$ & $\begin{array}{l}\geq 65 \text { y; reimbursed } \\
\text { NSAIDs; population- } \\
\text { based }\end{array}$ & $\begin{array}{l}\text { Dispensed NS-NSAID, } \\
\text { COX-2, or aspirin } \\
>325 \mathrm{mg} / \text { day } \\
\text { (incident and } \\
\text { prevalent). Cannot } \\
\text { assess OTC use }\end{array}$ & $\begin{array}{l}\text { Misoprostol, PPIs } \\
\text { (omeprazole, } \\
\text { esomoprazole, } \\
\text { pantoprazole, and } \\
\text { lansoprazole), and } \\
\text { H2RAs (ranitidine, } \\
\text { famotidine, } \\
\text { cimetidine, and } \\
\text { nizatidine) (incident } \\
\text { and prevalent). } \\
\text { Cannot assess OTC } \\
\text { use; ranitidine was } \\
\text { available }\end{array}$ & Filled on same date & NR & $\begin{array}{l}\text { Mention that side } \\
\text { effects of misoprostol } \\
\text { can lead to } \\
\text { noncompliance }\end{array}$ \\
\hline Abraham 2005 & $\begin{array}{l}\text { Veterans' (VA) facilities, } \\
\text { USA; Jan 2002-Dec } \\
2002\end{array}$ & $\begin{array}{l}\text { Ascertain adherence to } \\
\text { evidence-based } \\
\text { guidelines for the } \\
\text { safe prescription of } \\
\text { NSAIDs among } \\
\text { patients at VA } \\
\text { facilities }\end{array}$ & $\begin{array}{l}\text { 18-99 y; dispensed } \\
\text { NSAID, salicylate } \\
>325 \mathrm{mg} / \text { day, or } \\
\text { coxib; population- } \\
\text { based }\end{array}$ & $\begin{array}{l}\text { Dispensed NSAID, } \\
\text { incident or prevalent } \\
\text { (NSAIDs: choline } \\
\text { magnesium } \\
\text { trisalicylate, } \\
\text { diclofenac, } \\
\text { diclofenac } \\
\text { potassium, diflusinal, } \\
\text { etodolac, fenoprofen } \\
\text { Ca, flurbiprofen, } \\
\text { ibuprofen, } \\
\text { indomethacin, } \\
\text { ketoprofen, ketorolac } \\
\text { tromethamine, } \\
\text { meclofenamate, } \\
\text { meloxicam, } \\
\text { nabumetone, } \\
\text { naproxen, oxaprozin, } \\
\text { phenylbutazone, } \\
\text { piroxicam, salsalate, } \\
\text { sulindac, tolmetin); } \\
\text { coxibs (celecoxib, } \\
\text { rofecoxib, } \\
\text { valdecoxib); } \\
\text { salicylates }>325 \text { mg }\end{array}$ & $\begin{array}{l}\text { Dispensed } \\
\text { gastroprotective } \\
\text { agent (cimetidine, } \\
\text { ranitidine, nizatidine, } \\
\text { famotidine, } \\
\text { omeprazole, } \\
\text { rabeprazole, } \\
\text { pantoprazole, } \\
\text { esomeprazole, } \\
\text { lansoprazole, or } \\
\text { misoprostol) } \\
\text { (probably incident } \\
\text { and prevalent) }\end{array}$ & $\begin{array}{l}\text { Gastroprotective agent } \\
\text { dispensed during index } \\
\text { NSAID prescription } \\
\text { (first NSAID } \\
\text { prescription recorded } \\
\text { in study period) }\end{array}$ & NR & $\begin{array}{l}\text { Adherence to guideline } \\
\text { (co-prescription for } \\
\text { patients >65 y, with } \\
\text { history of upper Gl } \\
\text { events, use of } \\
\text { anticoagulants or } \\
\text { corticosteroids, or } \\
\text { exceeding } \\
\text { recommended NSAID } \\
\text { dose). Adherence to } \\
\text { evidence-based } \\
\text { guidelines for safe } \\
\text { prescription of } \\
\text { NSAIDs among high- } \\
\text { risk individuals is low, } \\
\text { even in presence of } \\
\text { multiple risk factors; } \\
\text { and lower in long- } \\
\text { term NSAIDs }\end{array}$ \\
\hline
\end{tabular}


Supplementary Table 3. Continued

\begin{tabular}{|c|c|c|c|c|c|c|c|c|}
\hline Study & Setting & Objective & Eligibility & NSAID exposure & $\begin{array}{l}\text { Gastroprotective agent } \\
\text { exposure }\end{array}$ & $\begin{array}{l}\text { Concomitant/ } \\
\text { co-prescription }\end{array}$ & Sensitivity analysis & $\begin{array}{l}\text { Outcomes measured/ } \\
\text { conclusion }\end{array}$ \\
\hline Johnell 2008 & Sweden; Oct-Dec 2005 & $\begin{array}{l}\text { Assess rate of and } \\
\text { factors affecting co- } \\
\text { prescription }\end{array}$ & $\begin{array}{l}\geq 75 \text { y; dispensed } \\
\quad \text { medications; } \\
\quad \text { population-based }\end{array}$ & $\begin{array}{l}\text { Dispensed any M01A, } \\
\text { excluding M01AX } \\
\text { (incident and } \\
\text { prevalent); cannot } \\
\text { assess OTC use }\end{array}$ & $\begin{array}{l}\text { Dispensed any PPI, } \\
\text { misoprostol, or H2 } \\
\text { antagonists (incident } \\
\text { and prevalent); } \\
\text { cannot assess OTC } \\
\text { use, PPIs available }\end{array}$ & $\begin{array}{l}\text { NR; implies overlap by } \\
\text { dose }\end{array}$ & NR & $\begin{array}{l}\text { Underutilization of } \\
\text { gastroprotective } \\
\text { agents was more } \\
\text { common than } \\
\text { overutilization }\end{array}$ \\
\hline Valkhoff 2010 & $\begin{array}{l}\text { Netherlands; Jan 1996- } \\
\quad \text { Dec } 2006\end{array}$ & $\begin{array}{l}\text { Examine time trends in } \\
\text { preventative } \\
\text { strategies }\end{array}$ & $\begin{array}{l}\geq 50 \text { y; prescribed new } \\
\text { NSAID in general } \\
\text { practice; no prior } \\
\text { gastroprotective } \\
\text { agents }\end{array}$ & $\begin{array}{l}\text { Newly prescribed NS- } \\
\text { NSAIDs, coxibs, or } \\
\text { high-dose aspirin } \\
\text { (>325 mg/day) } \\
\text { excluding topical, } \\
\text { and no use within } \\
\text { last } 6 \text { mo (incident } \\
\text { use); cannot assess } \\
\text { OTC use }\end{array}$ & $\begin{array}{l}\text { Prescribed H2RA, PPI, or } \\
\text { misoprostol } \\
\text { (including } \\
\text { misoprostol/ } \\
\text { diclofenac } \\
\text { combination) within } \\
2 \text { days of new NSAID } \\
\text { prescription and no } \\
\text { use within last } 6 \text { mo } \\
\text { (incident use); } \\
\text { cannot assess OTC } \\
\text { use, H2 blockers } \\
\text { available }\end{array}$ & Prescribed within 2 days & $\begin{array}{l}\text { Shown to have positive } \\
\text { predictive value of } \\
85 \%-90 \%\end{array}$ & $\begin{array}{l}\text { Underutilization has } \\
\text { decreased from } \\
1996-2006, \text { but } \\
60 \% \text { of at-risk NSAID } \\
\text { users still do not } \\
\text { receive } \\
\text { gastroprotection }\end{array}$ \\
\hline $\begin{array}{l}\text { Superceneau } \\
2010\end{array}$ & $\begin{array}{l}\text { Nova Scotia, Canada; } \\
\quad \text { Apr 1998-Mar } 2003\end{array}$ & $\begin{array}{l}\text { Describe rate, timing, } \\
\text { and duration of Gl } \\
\text { prophylaxis }\end{array}$ & $\begin{array}{l}\geq 65 \text { y; reimbursed new } \\
\text { NSAID; population- } \\
\text { based }\end{array}$ & $\begin{array}{l}\text { Reimbursed NSAIDs } \\
\text { including celecoxib, } \\
\text { rofecoxib, aspirin, } \\
\text { diclofenac, diflunisal, } \\
\text { etodolac, fenoprofen, } \\
\text { floctafenine, } \\
\text { flurbiprofen, } \\
\text { ibuprofen, } \\
\text { indomethacin, } \\
\text { ketoprofen, } \\
\text { ketorolac, mefenamic } \\
\text { acid, meloxicam, } \\
\text { nabumetone, } \\
\text { naproxen, oxaprozin, } \\
\text { piroxicam, salsalate, } \\
\text { sulindac, tenoxicam, } \\
\text { tiaprofenic acid and } \\
\text { tolmetin, no use in } \\
\text { last year (incident } \\
\text { use); cannot assess } \\
\text { OTC use }\end{array}$ & $\begin{array}{l}\text { Reimbursed H2RA, PPI, } \\
\text { or misoprostol, no } \\
\text { use in last } 2 \text { mo } \\
\text { (incident use) and } \\
\text { prevalent use } \\
\text { analyzed separately; } \\
\text { cannot assess OTC } \\
\text { use }\end{array}$ & $\begin{array}{l}\text { Use of both meds } \\
\text { in the same month; or } \\
\text { gastroprotective agent } \\
\text { prescribed in same } \\
\text { month as new NSAID } \\
\text { prescription }\end{array}$ & $\begin{array}{l}2 \text { analyses using } \\
\text { different definitions } \\
\text { of co-prescription }\end{array}$ & $\begin{array}{l}\text { Rate of co-prescription } \\
\text { was low; most } \\
\text { seniors received } \\
\text { regular-dose H2RAs } \\
\text { despite evidence that } \\
\text { this is not sufficient } \\
\text { prophylaxis }\end{array}$ \\
\hline Thiefin 2011 & France; Jun-Aug 2006 & $\begin{array}{l}\text { Assess the prevalence } \\
\text { of gastroprotective } \\
\text { agent prescription in } \\
\text { patients treated with } \\
\text { NSAIDs in France and } \\
\text { analyze the } \\
\text { determinants of this } \\
\text { prescription }\end{array}$ & $\begin{array}{l}\geq 18 \text { y; prescribed } \\
\text { NSAIDs }\end{array}$ & $\begin{array}{l}\text { GP-reported prescription } \\
\text { of NS-NSAIDs: } \\
\text { propionic acid } \\
\text { derivatives, } \\
\text { phenylacetic acids, } \\
\text { oxicams, other; COX- } \\
\text { 2: celecoxib }\end{array}$ & $\begin{array}{l}\text { GP-reported prescription } \\
\text { of PPI, H2RA, or } \\
\text { misoprostol (probably } \\
\text { incident and } \\
\text { prevalent use) }\end{array}$ & $\begin{array}{l}\text { Concomitant prescription } \\
\text { of gastroprotective } \\
\text { agent with NSAID }\end{array}$ & NR & $\begin{array}{l}\text { Gastroprotection is still } \\
\text { largely } \\
\text { underprescribed. } \\
\text { Only half of NSAID } \\
\text { users }>65 \text { y are } \\
\text { prescribed } \\
\text { gastroprotective } \\
\text { agents }\end{array}$ \\
\hline
\end{tabular}


Supplementary Table 3. Continued

\begin{tabular}{|c|c|c|c|c|c|c|c|c|}
\hline Study & Setting & Objective & Eligibility & NSAID exposure & $\begin{array}{l}\text { Gastroprotective agent } \\
\text { exposure }\end{array}$ & $\begin{array}{l}\text { Concomitant/ } \\
\text { co-prescription }\end{array}$ & Sensitivity analysis & $\begin{array}{l}\text { Outcomes measured/ } \\
\text { conclusion }\end{array}$ \\
\hline Gulmez 2011 & $\begin{array}{l}\text { France; Aug 2003-Jul } \\
\quad 2004\end{array}$ & $\begin{array}{l}\text { Test adherence to } \\
\text { Beer's criteria and } \\
\text { French guidelines }\end{array}$ & $\begin{array}{l}\geq 65 \mathrm{y} ; \text { reimbursed } \\
\text { NSAID }+ \\
\text { osteoarthritis; } \\
\text { population-based }\end{array}$ & $\begin{array}{l}\text { Dispensed high-dose } \\
\text { (anti-inflammatory) } \\
\text { celecoxib, rofecoxib, } \\
\text { or NSAIDs; divided } \\
\text { into long-term (>6 } \\
\text { mo supply } \\
\text { dispensed) and } \\
\text { short-term users, } \\
\text { incident and } \\
\text { prevalent }\end{array}$ & $N R$ & $\mathrm{NR}$ & NR & $\begin{array}{l}\text { Most common } \\
\text { inappropriate use } \\
\text { was } 2 \text { different } \\
\text { NSAIDs in same } \\
\text { month or NSAID + } \\
\text { platelet aggregation } \\
\text { inhibitor }\end{array}$ \\
\hline Ljung 2011 & Sweden; 2008 & $\begin{array}{l}\text { Estimate use of } \\
\text { interacting drugs and } \\
\text { gastroprotective } \\
\text { agents }\end{array}$ & $\begin{array}{l}\geq 65 \mathrm{y} ; \geq 1 \text { NSAID } \\
\quad \text { reimbursement; } \\
\text { population-based }\end{array}$ & $\begin{array}{l}\text { Dispensed ATC class } \\
\text { M01A, excluding } \\
\text { glucosamine divided } \\
\text { into }<30 \text { doses, } 30- \\
180 \text { doses, and } \\
>180 \text { doses } \\
\text { (incident and } \\
\text { prevalent use); } \\
\text { cannot assess OTC } \\
\text { use }\end{array}$ & $\begin{array}{l}\text { Any dispensed H2RAs, } \\
\text { misoprostol, or PPIs } \\
\text { (incident and } \\
\text { prevalent use); } \\
\text { cannot assess OTC } \\
\text { use, omeprazole } \\
\text { available }\end{array}$ & Any time in same year & NR & $\begin{array}{l}\text { Prescribers should be } \\
\text { aware of interactions } \\
\text { between NSAIDs and } \\
\text { other medications. } \\
\text { Increased use of } \\
\text { gastroprotective } \\
\text { medication may be } \\
\text { justified }\end{array}$ \\
\hline Bell 2011 & $\begin{array}{l}\text { Finland; September } \\
\quad 2003\end{array}$ & $\begin{array}{l}\text { Estimate prevalence } \\
\text { and predictors of } \\
\text { SSRI/NSAID co- } \\
\text { prescription and } \\
\text { investigate use of } \\
\text { gastroprotective } \\
\text { agents }\end{array}$ & $\begin{array}{l}\text { Residents of long-term } \\
\text { care wards in } \\
\text { Helsinki, Finland; } \\
\text { complete medication } \\
\text { data available }\end{array}$ & $\begin{array}{l}\text { Regular use of oral } \\
\text { diclofenac, etodolac, } \\
\text { ibuprofen, } \\
\text { indomethacin, } \\
\text { ketoprofen, } \\
\text { mefenamic acid, } \\
\text { nabumetone, } \\
\text { naproxen, piroxicam, } \\
\text { tolfenamic acid, and } \\
\text { aspirin (including } \\
\text { low-dose aspirin). Not } \\
\text { coxibs. (prevalent } \\
\text { use); OTC use NA }\end{array}$ & $\begin{array}{l}\text { Regular use of PPIs and } \\
\text { histamine H2RAs } \\
\text { (prevalent use). } \\
\text { There were no } \\
\text { regular users of } \\
\text { misoprostol; OTC use } \\
\text { NA }\end{array}$ & $\begin{array}{l}\text { Both medications regularly } \\
\text { used }\end{array}$ & NR & $\begin{array}{l}\text { Many subjects were } \\
\text { exposed to } \\
\text { medications that } \\
\text { increase risk; only } \\
\text { about one-fourth } \\
\text { were prescribed a } \\
\text { gastroprotective drug }\end{array}$ \\
\hline Morini 2011 & Rome, Italy; NR (2010) & $\begin{array}{l}\text { Assess the management } \\
\text { of NSAID users in } \\
\text { primary care, in } \\
\text { relation to the } \\
\text { appropriate use of } \\
\text { gastroprotective } \\
\text { therapies }\end{array}$ & $\begin{array}{l}\text { Primary care patients } \\
\text { already taking } \\
\text { NSAIDs }>3 \text { times } / \text { wk } \\
\text { for }>6 \text { mo }\end{array}$ & $\begin{array}{l}\text { Practitioner-reported } \\
\text { use of NSAIDs, COX- } \\
2 \mathrm{~s} \text {, or antiplatelet } \\
\text { agents (aspirin, } \\
\text { ticlopidine, or } \\
\text { clopidogrel) } \\
\text { (prevalent use) }\end{array}$ & $\begin{array}{l}\text { Practitioner-reported } \\
\text { use of PPI, H2RA, or } \\
\text { misoprostol (probably } \\
\text { incident and } \\
\text { prevalent use) }\end{array}$ & $\begin{array}{l}\text { Both medications reported } \\
\text { by practitioner at time } \\
\text { of assessment }\end{array}$ & NR & $\begin{array}{l}\text { To ensure the correct } \\
\text { prescription of } \\
\text { gastroprotective } \\
\text { therapy for NSAID } \\
\text { users, tools to } \\
\text { support practitioners } \\
\text { further are required }\end{array}$ \\
\hline
\end{tabular}


Supplementary Table 3. Continued

\begin{tabular}{|c|c|c|c|c|c|c|c|c|}
\hline Study & Setting & Objective & Eligibility & NSAID exposure & $\begin{array}{l}\text { Gastroprotective agent } \\
\text { exposure }\end{array}$ & $\begin{array}{l}\text { Concomitant/ } \\
\text { co-prescription }\end{array}$ & Sensitivity analysis & $\begin{array}{l}\text { Outcomes measured/ } \\
\text { conclusion }\end{array}$ \\
\hline \multicolumn{9}{|l|}{ Efficacy } \\
\hline Abraham 2010 & $\begin{array}{l}\text { VA facilities, USA; Jan } \\
2000-\text { Dec } 2004\end{array}$ & $\begin{array}{l}\text { Effect of concomitant } \\
\text { PPIs on } \\
\text { hospitalization and } \\
\text { resource use }\end{array}$ & $\begin{array}{l}\text { 65-99 years; dispensed } \\
\text { NSAIDs; had Gl event } \\
\text { recorded in database }\end{array}$ & $\begin{array}{l}\text { Dispensed aspirin, } \\
\text { choline, or salicylate } \\
\text { >325 mg/day; } \\
\text { diclofenac, diflunisal, } \\
\text { etodolac, fenoprofen, } \\
\text { flurbiprofen, } \\
\text { ibuprofen, } \\
\text { indomethacin, } \\
\text { ketoprofen, } \\
\text { ketorolac, } \\
\text { meclofenamate, } \\
\text { meloxicam, } \\
\text { nabumetone, } \\
\text { naproxen, oxaprozin, } \\
\text { phenylbutazone, } \\
\text { piroxicam, sulindac, } \\
\text { tolmetin, rofecoxib, } \\
\text { valdecoxib, or } \\
\text { celecoxib (full dose); } \\
\text { >5 days, incident } \\
\text { users (none in last } 6 \\
\text { mo). Cannot assess } \\
\text { OTC use }\end{array}$ & $\begin{array}{l}\text { Dispensed } \\
\text { esomeprazole, } \\
\text { lansoprazole, } \\
\text { omeprazole, } \\
\text { pantoprazole, and } \\
\text { rabeprazole } \\
\text { (therapeutic doses, } \\
\text { incident and } \\
\text { prevalent). Cannot } \\
\text { assess OTC use, only } \\
\text { low-dose H2RAs } \\
\text { available }\end{array}$ & $\begin{array}{l}\text { Any overlap based on } \\
\text { dispensed doses }\end{array}$ & Yes & $\begin{array}{l}\text { UGIE by ICD code/if } \\
\text { NSAID-UGIE occurs, } \\
\text { the reduction in need } \\
\text { for hospitalization } \\
\text { results in a cost } \\
\text { savings }\end{array}$ \\
\hline Vonkeman 2007 & $\begin{array}{r}\text { Enschede, Netherlands; } \\
\text { Nov 2001-Dec } 2003\end{array}$ & $\begin{array}{l}\text { Determine risk factors } \\
\text { for serious ulcers and } \\
\text { compare } \\
\text { effectiveness of } \\
\text { different preventative } \\
\text { strategies }\end{array}$ & $\begin{array}{l}\text { Hospitalized with } \\
\text { serious ulcer + using } \\
\text { NSAIDs }\end{array}$ & $\begin{array}{l}\text { Self-reported NSAIDs } \\
\text { including COX-2s and } \\
\text { aspirin }>100 \mathrm{mg} / \\
\text { day, at time of } \\
\text { diagnosis; prevalent }\end{array}$ & $\begin{array}{l}\text { Self-reported } \\
\text { misoprostol, PPIs, or } \\
\text { H2 blockers, at time } \\
\text { of diagnosis; } \\
\text { prevalent }\end{array}$ & "Concomitant" & NR & $\begin{array}{l}\text { Hospitalized with } \\
\text { serious ulcer/ } \\
\text { concomitant PPIs } \\
\text { (but not selective } \\
\text { COX-2 inhibitors) } \\
\text { were associated with } \\
\text { reduced risk for } \\
\text { NSAID ulcer } \\
\text { complications }\end{array}$ \\
\hline Vonkeman 2008 & Same & $\begin{array}{l}\text { Assess cost- } \\
\text { effectiveness of } \\
\text { concomitant PPIs } \\
\text { with NSAIDs }\end{array}$ & Same & Same & Same & Same & Same & $\begin{array}{l}\text { Concomitant use of PPIs } \\
\text { for prevention of } \\
\text { NSAID ulcer } \\
\text { complications costs } \\
€ 4907 \text { per NSAID } \\
\text { ulcer complication } \\
\text { prevented when } \\
\text { using the least costly } \\
\text { PPIs }\end{array}$ \\
\hline \multicolumn{9}{|l|}{ Other } \\
\hline Dries 2009 & $\begin{array}{l}\text { Houston, USA; Jan } \\
\text { 2000-Dec } 2002\end{array}$ & $\begin{array}{l}\text { Assess prescribing } \\
\text { intent }\end{array}$ & $\begin{array}{c}\geq 65 \mathrm{y} \text {; dispensed } \\
\text { NSAID + PPI }\end{array}$ & $\begin{array}{l}\text { Prescribed NS-NSAID, } \\
\text { COX-2 (incident and } \\
\text { prevalent); does not } \\
\text { address OTC use }\end{array}$ & $\begin{array}{l}\text { Prescribed PPI (incident } \\
\text { and prevalent); OTC } \\
\text { PPIs not available } \\
\text { during study period }\end{array}$ & At least 5 days of overlap & NR & $\begin{array}{l}\text { Gastroprotection was } \\
\text { poorly recognized as } \\
\text { an indication for PPI } \\
\text { prescription, except } \\
\text { by rheumatologists } \\
\text { and in highly } \\
\text { comorbid patients }\end{array}$ \\
\hline
\end{tabular}

NOTE. Studies are referenced by their first author and year of publication.

ATC, Anatomical Therapeutic Chemical Classification System; GP, general practitioner; ICD, International Classification of Diseases; NA, not applicable; NR, not reported; OTC, over-the-counter; UGIE, upper Gl event.

${ }^{a}$ Date was determined through communication with Dr Morini. 